\title{
Potential for an underwater glider component as part of the Global Ocean Observing System
}

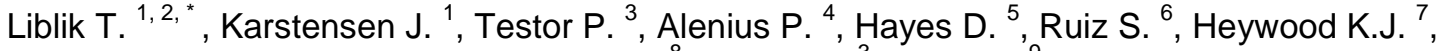 \\ Pouliquen Sylvie ${ }^{8}$, Mortier L. ${ }^{3}$, Mauri E. ${ }^{9}$
}

${ }^{1}$ GEOMAR Helmholtz Centre for Ocean Research Kiel, Kiel, Germany

${ }^{2}$ Marine Systems Institute at Tallinn University of Technology, Tallinn, Estonia

${ }^{3}$ CNRS, Université Pierre et Marie Curie (Paris 06), UMR 7159, Laboratoire d'Océanographie et de

Climatologie: Expérimentations et Approches Numériques (LOCEAN), Paris, France

${ }^{4}$ Finnish Meteorological Institute, Helsinki, Finland

${ }^{5}$ Oceanography Centre at University of Cyprus, Nicosia, Cyprus

${ }_{7}^{6}$ Mediterranean Institute for Advanced Studies, IMEDEA, Esporles, Illes Balears, Spain

${ }^{7}$ Centre for Ocean and Atmospheric Sciences, School of Environmental Sciences, University of East

Anglia, Norwich, UK

${ }^{8}$ Numerical and Marine Infrastructures Department, IFREMER, Plouzané, France

${ }^{9}$ Istituto Nazionale di Oceanografia e di Geofisica Sperimentale, Trieste, Italy

* Corresponding author : T. Liblik, email address : taavi.liblik@msi.ttu.ee

\begin{abstract}
:
The contributions of autonomous underwater gliders as an observing platform in the in-situ global ocean observing system (GOOS) are investigated. The assessment is done in two ways: First, the existing insitu observing platforms contributing to GOOS (floats, surface drifters, moorings, research/commercial ships) are characterized in terms of their current capabilities in sampling key physical and biogeochemical oceanic processes. Next the gliders' capabilities are evaluated in the context of key applications. This includes an evaluation of 140 references presented in the peer-reviewed literature.

It is found that GOOS has adequate coverage of sampling in the open ocean for several physical processes. There is a lack of data in the present GOOS in the transition regions between the open ocean and shelf seas. However, most of the documented scientific glider applications operate in this region, suggesting that a sustained glider component in the GOOS could fill that gap. Glider data are included for routine product generation (e.g. alerts, maps). Other noteworthy process-oriented applications where gliders are important survey tools include local sampling of the (sub)mesoscale, sampling in shallow coastal areas, measurements in hazardous environments, and operational monitoring. In most cases, the glider studies address investigations and monitoring of processes across multiple disciplines, making use of the ease to implement a wide range of sensors to gliders. The maturity of glider operations, the wide range of applications that map onto growing GOOS regional needs, and the maturity of glider data flow all justify the formal implementation of gliders into the GOOS. Remaining challenges include the execution of coordinated multinational missions in a sustained mode as well as considering capacity-building aspects in glider operations as well as glider data use.
\end{abstract}


Keywords : Global ocean observing system, GOOS, Underwater glider, Sustained observations 


\section{1. Introduction}

2 Since first prototype testing in the early nineties (Simonetti 1992) underwater gliders have

3 been rapidly taking up an important role in ocean observing and research (see Testor et al.

42010 and Rudnick 2015 for a comprehensive overview). This rapid transition towards a widely used observing platform can first of all be attributed to the fact that glider observations provide critical data for many applications. Historically, gliders have been used most frequently by scientists to observe particular oceanographic processes. Increasing interest of navies from different countries on the operations on coastal waters for naval operations (e.g. Renaud 2003) has contributed to the rapid development of glider technology as well. Underwater gliders use a buoyancy engine to survey the ocean interior along saw-tooth paths. Their operation times are typically of up to several months, depending on battery capacity and sampling configuration. Glider manufacturers and users have implemented a wide range of sensors on the platform and various physical and biogeochemical parameters can be recorded, many of them accessible in near real time.

Testor et al. (2010) gave a review of requirements and challenges of a global coordination for efficient use of underwater gliders. One of the recommendations was the establishment of a global glider system as an extension of the Global Ocean Observing System (GOOS). This idea is further elaborated in the assessment presented here, that benefits from a consolidation of national glider activities, namely the pan-European glider infrastructure design project, Gliders for Research, Ocean Observation and Management (GROOM). One of the main outcomes of GROOM was the identification of the need for a centralized coordinating body that would act as a centre of reference for the nascent European glider network infrastructure, by providing a platform for exchanging expertise, experience, equipment, facilities, and services and develop data sharing protocols and policies. Much of this is happening already on an informal, fragmented basis in Europe, but of course also in other regions such as Australia, in the context of the Integrated Marine Observing System (IMOS) Ocean Gliders facility, and the United States for example in the context of the Ocean Observatories Initiative (OOI) or the Glider Operations Center (GOC) at the Naval Oceanographic Office (NAVOCEANO). Regional US glider observing groups (Rutgers University, University of 
1 The Global Ocean Observing System (GOOS) is a permanent system for coordinating the 2 global ocean observatory efforts including infrastructure, data flow and data processing. 3 Ocean processes operate on time scales from fractions of a second to multiple decades 4 temporally and from millimetres to thousands of kilometres spatially (Ruhl et al. 2011).

5 Monitoring the ocean in four dimensions and across disciplines therefore requires integration 6 of data collected from a multiplatform system (e.g. Summerhayes 2002, table 1). Only a 7 concerted use of individual platform sampling strengths can overcome other platform weaknesses and limitations. Currently GOOS comprises observing efforts carried out by ships, moorings, floats, surface drifters, marine mammals and sea level observatories (for example Fig. 1). Guidance to help identify observing requirements and implementations is provided via disciplinary expert groups (physics and climate, biology and ecosystem, and 12 biogeochemistry) and also by considering specific regional requirements (GOOS regional 13 alliances).

Defining observing needs depends on societal and scientific objectives as well as technological readiness (Lindstrom 2012). Roughly, the requirements fall under three main themes, which are, however, linked with each other: climate, ocean health, and real-time (operational) services.

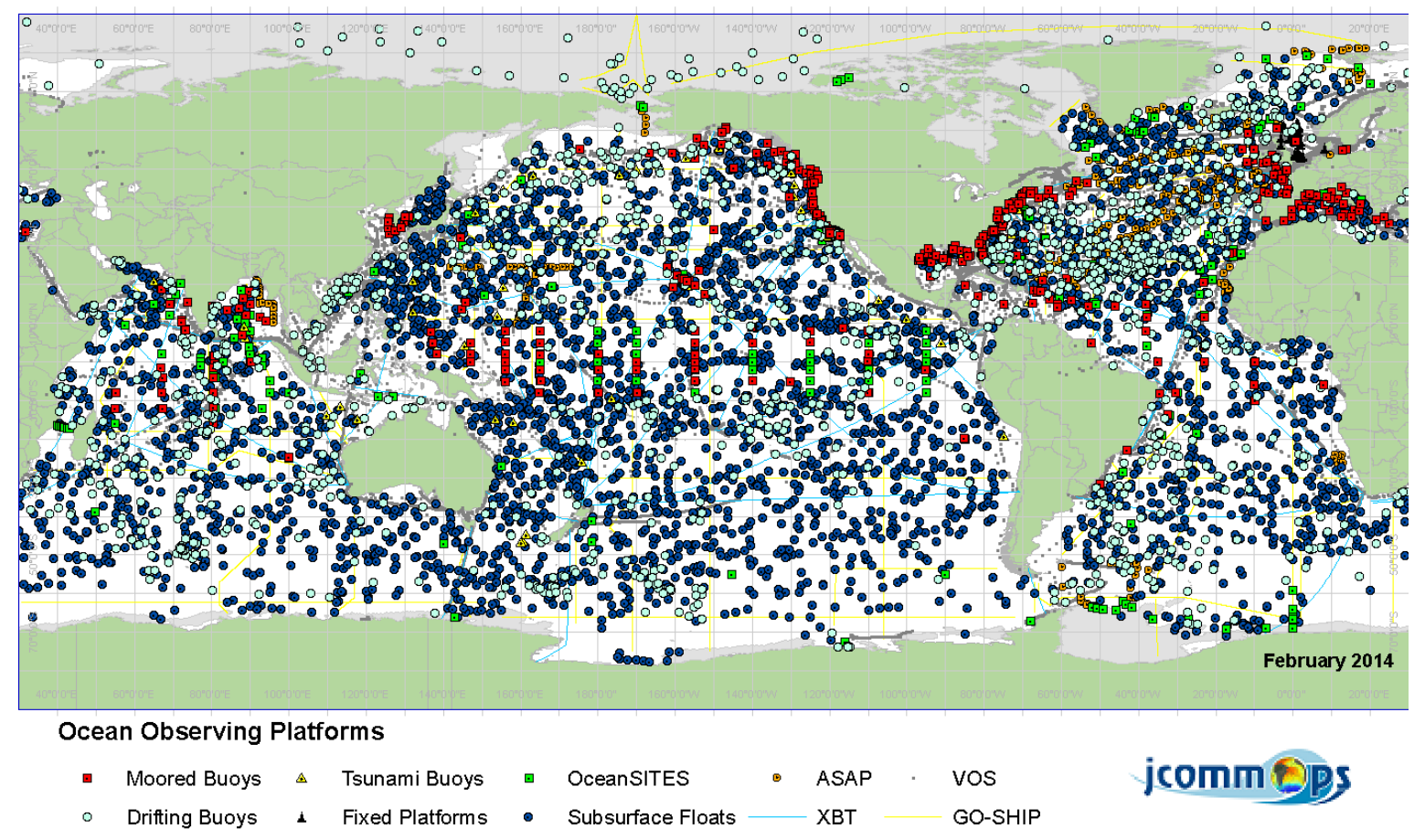


Figure 1. Summary map of all available in situ data as reported by JCOMMOPS in February 2014. Automated Shipboard Aerological Programme (ASAP) and Tsunami buoys are not under investigation in the present study (see http://www.jcommops.org/ for a recent update).

The coordination of the observational effort in GOOS is realized under the auspices of the WMO-IOC Joint Technical Commission for Oceanography and Marine Meteorology (JCOMM) through the Observations Coordination Group (OCG). Currently OCG provides coordination at the international level for oceanographic and marine observations from autonomous data buoys, Argo, OceanSITES moored buoys in the high seas, surface drifters, voluntary observing ships and ships of opportunity, and the global sea-level observing system, with the help of JCOMMOPS (JCOMM in-situ observing Platform Support Centre) and considering biogeochemical variables via the International Ocean Carbon Coordination Project (IOCCP).

In the present paper we evaluate the use of underwater gliders as an integral part of GOOS. We focus on the sampling capabilities of gliders and how they fit into the observing needs of GOOS. We first present a short description of sampling characteristics of the in-situ observing platforms currently organized in GOOS as well as ocean underwater gliders. We then assess the past use of gliders in ocean observing on the basis of reviewed publications making use of glider data and discuss the potential contribution of a glider component in GOOS.

\section{In-situ observing platforms in GOOS}

GOOS in-situ observing system consists of several platform types (e.g. Trtanj and Houston 2014; Legler et al. 2015): research vessels, profiling floats, surface drifters, ships of opportunity and voluntary observing ships, moorings, marine mammals and sea level stations. Each platform type has its own characteristics such as spatial and temporal resolution of sampling, coverage, endurance, costs, sustainability, sensor payload, accuracy, calibration issues and data transfer/availability. It is through the coordination of observing platforms in the GOOS that the limitations inherent in each of the platforms will be overcome and an optimized system is created that enables sampling relevant time, space, and parameters domains. 
1 An approach to analyse the potential contribution of each platform to the system is to overlay ocean processes with the spatial and temporal scales resolved by the various platforms in the framework of a "Stommel diagram" (Stommel 1963) (Figs 2 to 6, and Fig. 7 and summarized in Table 1). Temporally the upper limits are defined to be the lengths of time-series of the corresponding platform. Spatially both horizontal and vertical dimensions are taken into account. We limit this approach to an analysis of the capabilities in the frame of a simplified set up and with a primary focus on physical processes. For example the problems for a certain platform to sample in a dynamically active regions (e.g. sampling a fast flowing boundary current) is not adequately represented in the space/time diagram. Moreover, the sampling required to resolve phenomena related to other disciplines (e.g. biogeochemistry, biology) is not explicitly resolved, this is true for the space/time domains but also in relation to the parameter domains.

However, an attempt to consider the sensor/parameter availability of the GOOS observing platforms (Table 1) was done by focussing on parameters that are frequently measured with gliders and that resemble a subset of essential climate variables (Houghton et al. 2012). As such, the list of parameters shown in Table 1 is only a small subset of variables that can be potentially measured with the different in-situ observing platforms.

We do not discuss factors like costs, maintenance and endurance of observing platforms, data quality, accuracy of sensors, or logistics. All will play an important role in creating and maintaining a sustained system. The interested reader may find a summary of three years of glider infrastructure set-up, operational and maintenance costs of the case of European operators in GROOM (2014), including the wide range of estimated daily costs for operations and for emergency recoveries.

\section{Argo}

The global array of temperature and salinity profiling floats ("A real-time geostrophic array" Argo) is the prime example of a sustained network of observing platforms of global importance (Riser et al. 2016). The array was designed based on a well-defined scientific objective of global relevance, namely monitoring the upper ocean heat content variability with spatial resolution $3 \times 3$ degrees between latitudes $60^{\circ} \mathrm{N}$ and $60^{\circ} \mathrm{S}$ on seasonal and longer 
1 time scales. That required an array of 3000 floats sampling every 10 days the upper $2000 \mathrm{~m}$ 2 (White 1994; Argo Science Team 1998). An Argo float's sensor sampling rate is up to $1 \mathrm{~Hz}$ 3 depending on the transmission mode (Iridium, ARGOS). The full-resolution data or data 4 interpolated to standard depths are transmitted. Trajectory data of Argo floats allow 5 estimating current velocities at parking depth (set around $1000 \mathrm{~m}$ in the global basins, less in 6 enclosed seas like the Mediterranean).

7 In order to establish the array, international coordination efforts considered and properly 8 addressed the following: legal aspects for deployment and drift, data quality control and 9 timely distribution, formation and operation of coordination teams (data, science and 10 implementation). The currently operational array (defined by the floats accessible via the 11 Argo data centre) counts more than 3800 floats (as of March-2016, see 12 http://www.jcommops.org/board?t=Argo for an update). This "oversampling" against the core 13 science objective (upper ocean heat content variability) can be explained by the 14 implementation of data from "non-sustained", science project based deployments, such as about 250 floats that belong to the "pilot network" of floats that carry biogeochemical sensors 16 (oxygen, chlorophyll-a/fluorescence, Gruber et al. 2010). However, recently Durack et al. 17 (2016) have pointed that number of floats might decrease to $3200 \mathrm{in} 2018$ due to reduction in 18 Argo deployments. The ease in implementing floats into the sustained array has substantially 19 increased the data return against the defined science goal and allows for an improved use in 20 GOOS. 


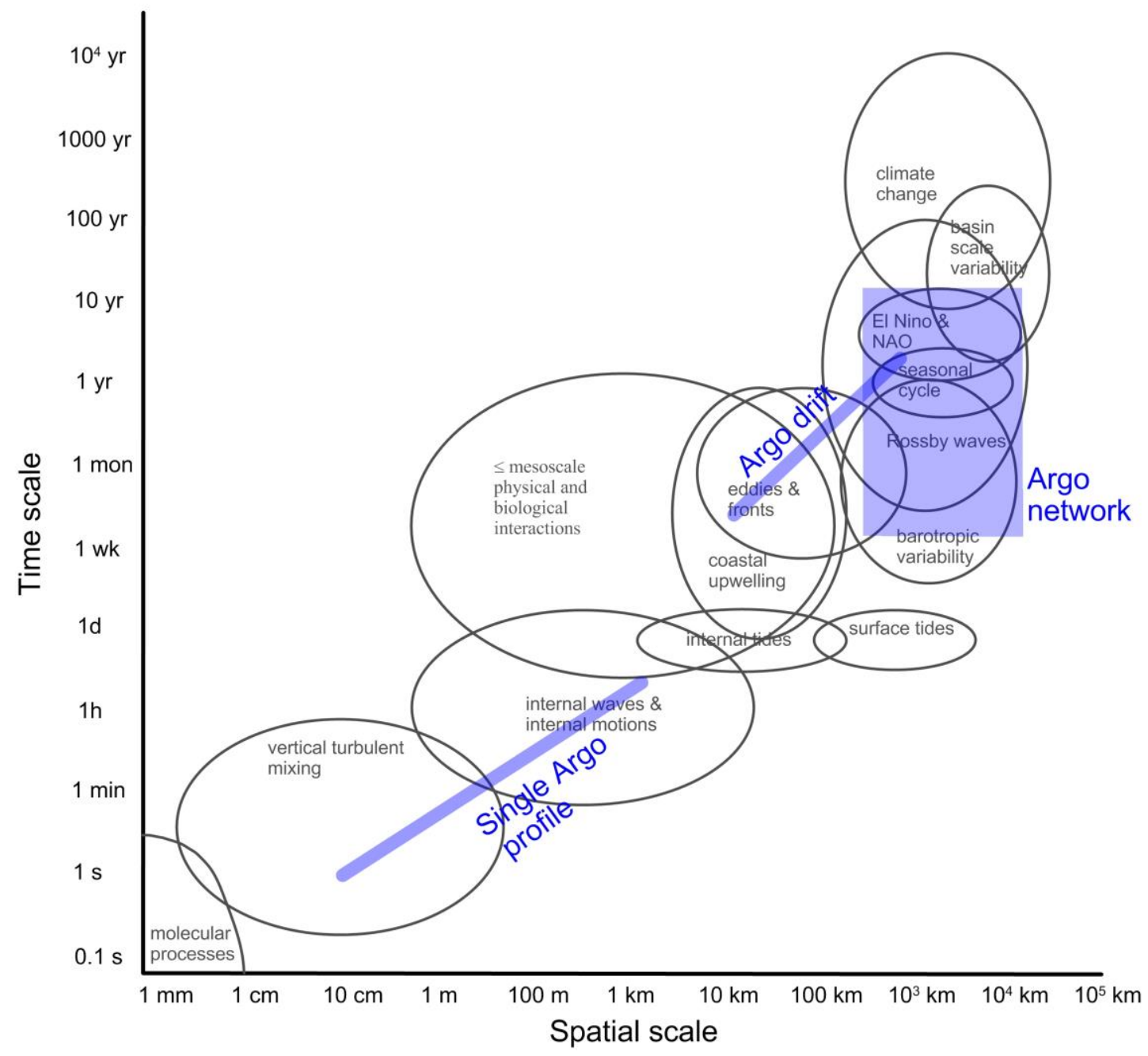

1

2 Figure 2. Time-space diagram of ocean and earth processes (after Ruhl et al. 2011) and

3 sampling capabilities of Argo. The sampling capabilities of both a single Argo float and a

4 network of floats (Argo network) are distinguished. Both vertical and horizontal dimensions

5 are considered in spatial scale.

6 Argo is considered a sustainable part of the polar oceans observing systems (Abrahamsen

7 2014) because under-ice operations are feasible using acoustic tracking during extended

8 periods of non-surfacing (Klatt et al. 2007). The planned extension of the depth range to 4000

9 and even 6000m (Roemmich et al. 2014) will extend the theoretically observable ocean

10 volume (currently it is only $48 \%$ due to the $2000 \mathrm{~m}$ depth limit) substantially. However, for

11 deep ocean observing the major limitation is currently the accuracy and stability of

12 temperature and salinity sensors. Other future developments include use of shallow floats that

13 can operate in regional seas (e.g. Baltic Sea; Purokoski et al. 2013; Coral Seas Kessler and 
1 Cravatte 2013) and air-deployable profiling floats to study hurricanes (alamo.whoi.edu). In

2 general the array as a whole cannot resolve processes at the mesoscale (Figure 2).

3 An important complementary source of CTD (Conductivity, Temperature, Depth) data in

4 polar, ice-covered regions in the Southern Ocean and Arctic stems from marine mammal 5 tagging (e.g. Fedak 2013). The sampling accuracies and resolution are relatively similar to 6 Argo floats, although they typically profile more frequently (normally one profile per day is 7 transmitted). These data sets are often treated similar to Argo float data in respect to automatized real-time and delayed mode quality control procedures but also in way in distributing the data.

\section{Global Drifter Program}

The Global Drifter Program (GDP) was introduced at the beginning of the 1980s (see Legler et al. 2015 for a recent review). The primary scientific objective of the GDP is a near-real time observing system for sea surface temperature (Zhang et al. 2010) and large-scale ocean surface circulation and its seasonal variability (Lumpkin et al. 2016). A coverage in 5 x 5 degrees squares was estimated as the minimal array design (Lumpkin et al. 2016; Fig. 3), translating to a need of about 1250 satellite tracked surface drifters to be operational. Individual floats can resolve mesoscale variability along their trajectory. Besides drift estimates, the GDP array provides sea surface temperature data as well as sea level pressure data (Keeley et al. 2008). The latter parameters are provided by about half of the drifters. The typical temporal resolution of drifter measurements after data processing is 6 hours (Lumpkin and King 2008). Single drifters (process studies) can be set to send their data two or three times per hour. As for the Argo array, drifters that have been launched in the framework of projects/process studies, and therefore are not part of the sustained system, have increased data availability for GOOS. At any given time, there are approximately 1440 drifters in operation and these data are freely available in real time either as individual drifter tracks or as gridded products. 


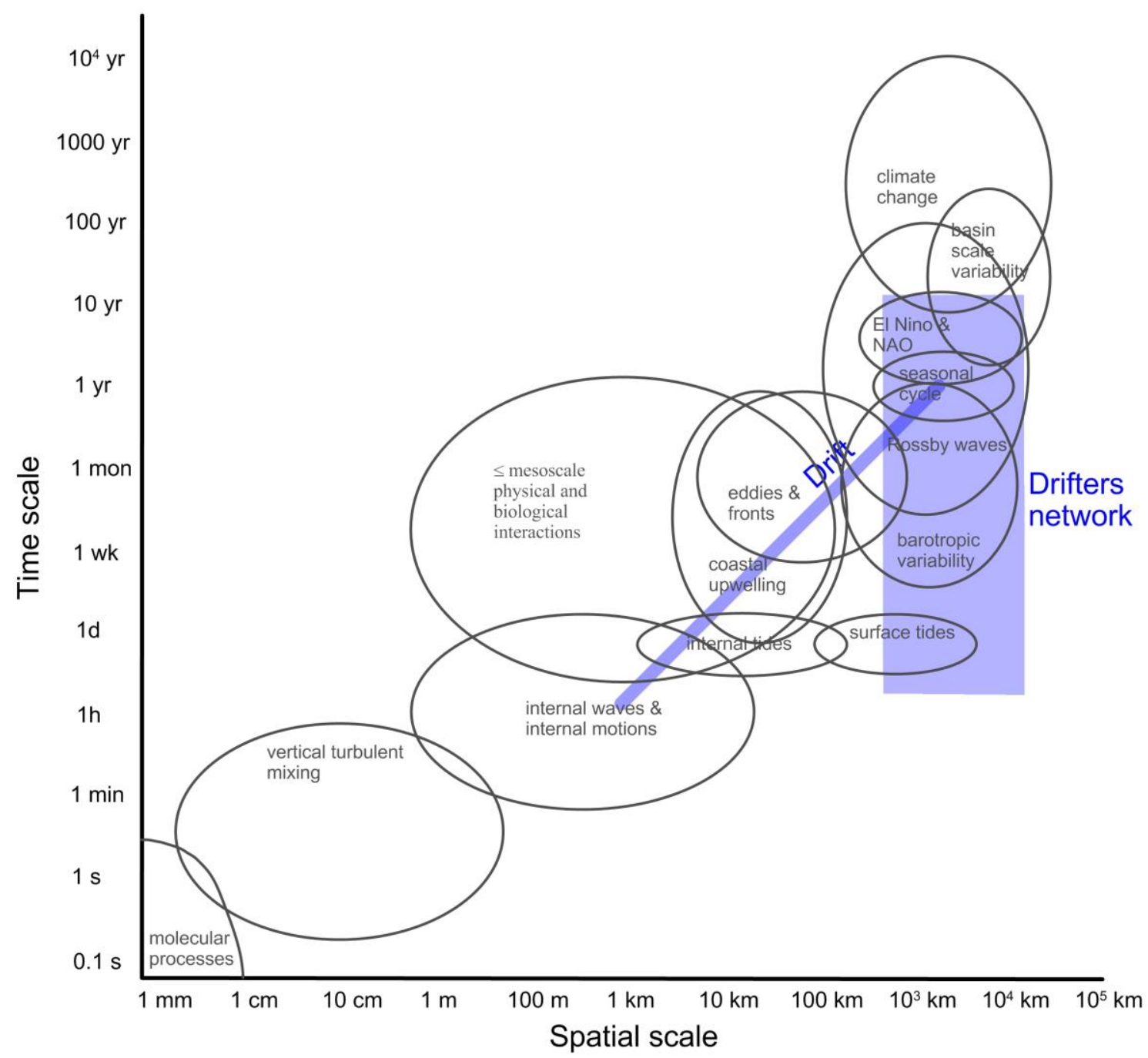

2 Figure 3. As Fig. 2 but for the global drifter network. Single drifter as well as the drifter

3 network are separated.

4 Since drifters have great ability to estimate currents in the upper ocean, they can be deployed

5 for local studies such as tracking oil spills (Sharma et al. 2010), and their data can be

6 efficiently used in search and rescue operations in the ocean (Breivik et al. 2013). In coastal

7 areas, drifters have been used in case studies to investigate dispersion or spreading of

8 substances. In ice-covered regions surface drifters become trapped in sea ice, so their typical

9 lifetime is reduced (Thompson et al. 2009) but may allow ice drift estimation instead (e.g.

10 Häkkinen et al. 2008, Leppäranta et al. 2001). 


\section{Ships of Opportunity and Voluntary Observing Ships}

2

\section{programs}

The Ships Observations Team (SOT) comprising the Ships of Opportunity Program (SOOP; Goni et al. 2010), the Voluntary Observing Ships Program (VOS; Kent et al. 2010), and the

Automated Shipboard Aerological Program (ASAG), coordinate the collection of underway measurements that are acquired on board merchant-, cruise- and research vessels (Smith et al. 2010, Legler et al. 2015). The VOS program was initiated in the $19^{\text {th }}$ century and it has been an important data source for marine climate (Worley et al. 2005). Of particular importance is the collection of data along repeated transects using merchant ship routes that have been maintained for many years and even decades (e.g. Vranes and Gordon 2005; Rossby and Zhang 2001).

The SOOP include upper ocean observations of temperature profiles using eXpendable BathyThermographs (XBTs) and temperature and salinity time series data collected near the surface with the thermosalinograph (TSG) from the ships' flow-through system. The XBT data bridge the heat content studies from pre-Argo era to the present day and were also used for the design of the Argo array (White 1994).

Dedicated XBT sections of VOS are often sampled with monthly resolution (e.g. the Oleander Project, Rossby and Zhang 2001) while various TSG tracks are repeated with even higher frequencies, depending on the route length. Re-visit can be from a couple of times a day in marginal seas (e.g. Lips et al. 2011) to several times a year in open ocean (e.g. Rossby and Zhang 2001; Feely et al. 2012).

XBT profile data are acquired with a horizontal resolution of typically $150 \mathrm{~km}$ along frequently visited transects (Fig. 4) and can be as high as $25 \mathrm{~km}$ for high resolution sections. Vertical resolution is $10 \mathrm{~m}$ and range down to about $750 \mathrm{~m}$ depth. The TSG is typically set to sample every 20 seconds and thus resolves horizontal scales of a few hundreds of metres after processing (Fig. 4). Thus automated underway measurements provide high-resolution data from the upper layer, which are very useful for front determination. TSG data are especially valuable in coastal zones, where global systems (Argo, GDP) might be too sparse. For comparison with satellite retrievals, TSG data have been used as instrumental reference, in 
1 particular for the recent satellite salinity missions (SMOS and Aquarius) (Hernandez et al. 2 2014).

3 The SOOP also collects current (Acoustic Doppler Current Profiler) data as well as 4 biogeochemical variables such as chlorophyll-a fluorescence, and partial pressure of $\mathrm{CO}_{2}$ 5 (Surface Ocean $\mathrm{CO}_{2}$ Atlas- SOCAT; Bakker et al. 2012). Under GOOS pilot project 6 FerryBox, underway systems are commonly used on-board passenger ferries in the North Sea 7 and the Baltic Sea (Hydes et al. 2010). For instance the Alg@Line project has used passenger 8 ferries for over 20 years (Rantajärvi 2003).

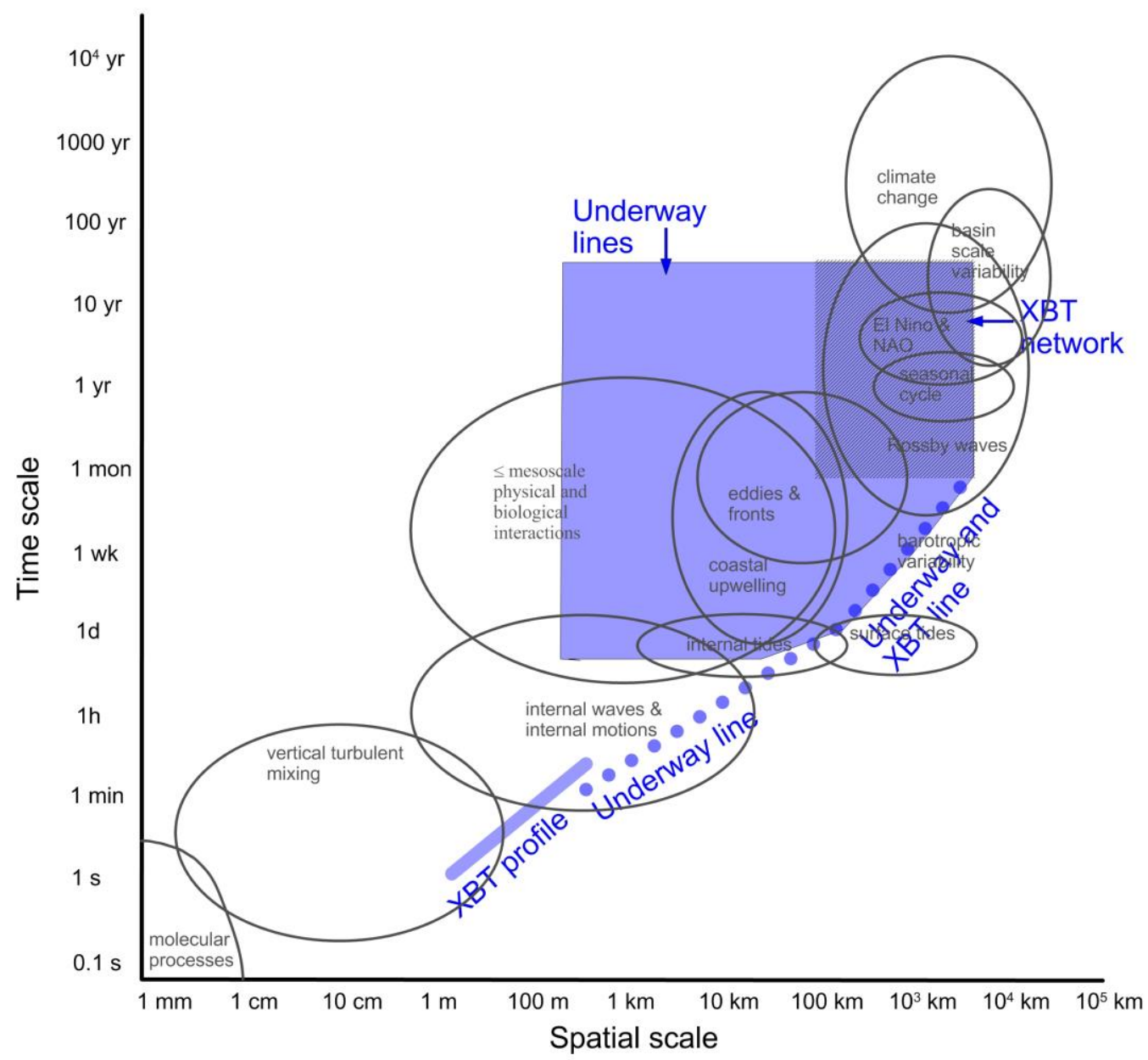

Figure 4. As Fig. 2 but for the XBT network and underway lines.

13 A special activity in SOOP is the collection of biological data in the context of the Global 14 Alliance of Continuous Plankton Recorder Surveys (GACS). The continuous plankton 
recorder is towed behind the ship at a depth of about $10 \mathrm{~m}$ where it collects plankton samples, which are later analysed in the laboratory (Reid et al. 2010). Often the data acquisition from XBT, TSG are (semi) automated and the data are transmitted in real-time through communication satellites (e.g. GOES, METEOSAT, ARGOS, Inmarsat systems) to dedicated data assembly centres as either BATHY or TESAC messages. The observations are compiled into bulletins and distributed globally via the GTS under JCOMM. The data are encoded in the international exchange format MEDSASCII, quality controlled by the operating agencies, and sent at 12-month intervals to the respective Regional National Oceanographic Data Centre (RNODC) for forwarding to the World Data Centres (WDCAs USA, Russia).

The assembly and incorporation of delayed mode SOOP/VOS data into the Global Temperature-Salinity Profile Program (GTSPP) data stream in a timely manner is an essential activity. Experience has shown that significant amounts of real time data are not being replaced with full resolution data versions, and that large quantities of additional data are only available in delayed mode. While these data are not available for operational use, they are critical for GCOS thus contributing to climate research.

\section{Research vessels and GO-SHIP}

Research vessels are important components of the ocean observing system, in particular for specialized and multidisciplinary studies, and studies that require data of high quality (e.g. climate studies). Many parameters cannot be measured by autonomous systems, at least not with the accuracy of those gathered by research vessels.

The open ocean sustained oceanographic measurements on research vessels is coordinated under the Global Ocean Ship-based Hydrographic Investigations Program (GO-SHIP; Hood et al. 2010). GO-SHIP assembles the high-quality and high-resolution observations of physical, chemical and biological parameters in full ocean depth resolution that originate from dedicated ship surveys. The sections are repeated multi-annually and provide critical data for long term changes of the ocean state. A very important activity within GO-SHIP is in defining standard procedures for sampling in order to assure high data quality and comparability over time and measuring platforms. 
1 Other sustainable sources of ship-gathered data are national monitoring programs, which are

2 often coordinated by intra-governmental bodies; such are e.g. HELCOM (for the Baltic Sea),

3 OSPAR (North-East Atlantic), BSIMAP (for the Black Sea) and AMAP (for the Arctic). Such

4 monitoring programs typically collect data on a monthly or seasonal basis.

5 Although not compulsory, many vessels are advised to provide collected data in near real time

6 on GTS or as BATHY or TESAC (e.g. data transmission to the Coriolis Data Centre,

7 Integrated Ocean Observing System US-IOOS and Australian Integrated Marine Observing

8 System IMOS ocean portal). The GO-SHIP panel, for instance, recommends the following data-release guidelines: preliminary dataset released within 6 weeks (e.g. all data measured on the ship), 6 months for final physical data and 1 year for final data of all other variables. Data from research ships have traditionally been assembled by National Oceanographic Data Centres (NODCs), regional centres, like the International Council for the Exploration of the Sea (ICES) and the North Pacific Marine Science Organization (PICES) and to global data centres, which are today part of the World Data System, WDS (http://www.icsu-wds.org/). A Pan-European infrastructure has been developed in the SeaDataNet project (Schaap and Lowry 2010) that provides one access point to the distributed national data centres.

\section{Tropical moored arrays and OceanSITES}

Moored systems acquire observations at fixed geographic locations and with instruments mounted at fixed depths (although mooring vertical displacement is inevitable during strong currents). Moorings deliver temporally high-resolution data (Fig. 5) and, as the payload capabilities are large, can host a variety of sensors of different complexity. The observations cover a wide spectrum of physical (incl. geophysical), biological, and biogeochemical parameters. The systems can extend over the whole water column including the air/sea interface. The configuration of the sensors along the mooring line defines the vertical resolution which is typically tens to hundreds of metres. Specific moorings equipped with profiler systems sample at a higher vertical resolution (e.g. Lips et al. 2011, Send et al. 2013, Zhou et al. 2013).

Real-time access to data from surface as well as subsurface instruments is critical when using the data in forecast models, e.g. in the context of seasonal prediction (e.g. TAO array, PIRATA array). The recovery of the sensors allows for post-calibration and high data quality 
1 is possible. Surface buoys are used for calibration/validation activities for satellite retrievals 2 or air/sea fluxes (Sun et al. 2003).

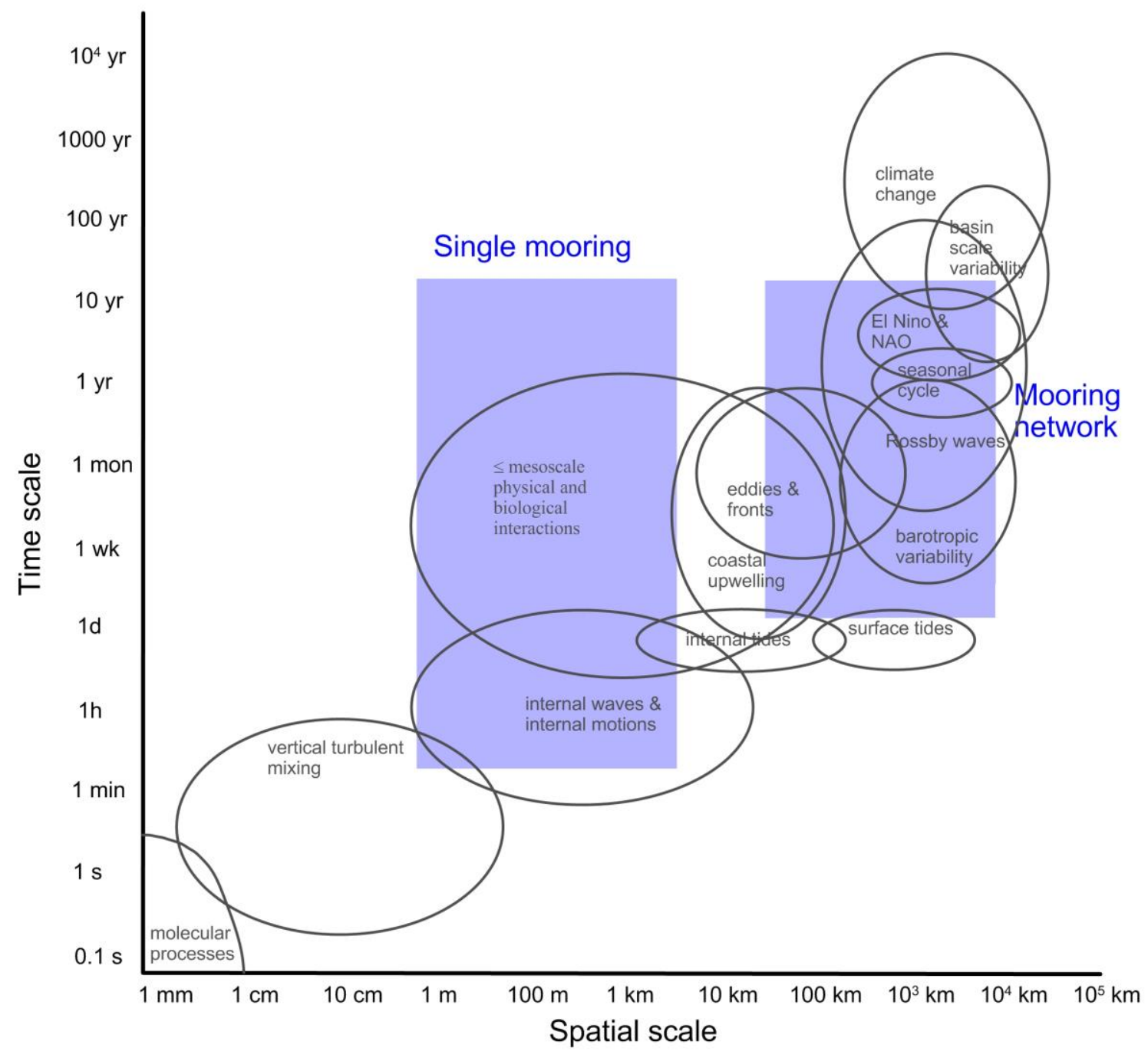

Figure 5. As Fig. 2 but for moorings.

6 Given different scientific and operational aspects, moorings have been organized in GOOS in

7 two groups: the tropical moored arrays and OceanSITES (Legler et al. 2015). The tropical

8 moored arrays have been designed for a specific scientific objective, to monitor the evolution

9 of the tropical ocean upper flow and temperature field in order to improve the forecast of tropical inter-annual and intra-seasonal variability such as El Nino Southern Oscillation and

11 the Madden Julian Oscillation. The moorings coordinated under OceanSITES (Send, Weller

12 et al. 2010) aim for long (several years) open ocean time series acquisition. As such most of 13 the moorings from the tropical moored arrays are also part of OceanSITES. The OceanSITES 
1 objectives include optimized configuration (e.g. sampling depth locations, deep ocean observing efforts) and in particular data management issues.

\section{$3 \quad$ Global Sea-Level Observing System}

4 The Global Sea-Level Observing System (GLOSS, e.g. Woodworth and Player 2008) is an

5 international programme coordinating a network of sea level monitoring gauges installed 6 along seashores around the world in over 70 countries. The GLOSS is incorporated into 7 tsunami warning systems. Other variables (e.g. near surface temperature) are often measured as well. Because of the importance of sea level extremes in coastal areas, a large fraction of the GLOSS transmit data in near real time $(<1 \mathrm{~h})$. The GLOSS provide data that is used to assess the link between regional and global sea level rise which is of high socioeconomic importance. The GLOSS has established standards in collecting and processing sea level data. Rather than discourage participation, this enables the network to expand, while still maintaining the quality of the observations (IOC, 1997).

\section{Glider observatories}

Most underwater gliders sample the ocean along slanted profiles between the surface and down to $1000 \mathrm{~m}$ or even $1500 \mathrm{~m}$ depth. Navigational devices on board (compass, pitch/roll sensors) ensure proper navigation during the dive. Comparison with a position estimate through GPS satellites at the surface is used to reset the start coordinates for the next dive and to estimate the dive-average current and the surface drift of the device. The glider moves horizontally about $30 \mathrm{~km}$ per day and the maximum endurance is typically a few months in the open ocean, but this depends on many factors such as number of dives per day, the type of sensors in use, the sampling strategy, the stratification, the currents, and diving depth. The U.S. OOI's global array of gliders has endurance of up to 1 year. For a typical diving speed of $0.15 \mathrm{~m} \mathrm{~s}^{-1}$ and sampling at $1 \mathrm{~Hz}$, the vertical resolution is $0.15 \mathrm{~m}$. Horizontal, vertical and temporal variability are all conflated in the observations and this has to be considered when analysing and interpreting the data. 
1 The suite of sensors that have been integrated or mounted on gliders is steadily growing.

2 Variables that can be measured include pressure, temperature, conductivity, chlorophyll- $a$

3 fluorescence, turbidity, chromophoric dissolved organic matter (CDOM) fluorescence,

4 dissolved oxygen, PAR (Photosynthetically Active Radiation), phycobilins, turbulence,

5 currents, wind, nitrate, animal presence and biomass, marine mammal detection (see summary

6 by GROOM 2015). For common physical or biogeochemical parameters, such as temperature,

7 conductivity or chl- $a$ fluorescence, the sampling rate is typically $1 \mathrm{~Hz}$, which allows gathering

8 processed data in vertical resolution of the same order as research-vessel collected profiles.

9 The horizontal distance between consecutive dives is in the order of 2-5 km in 1000-1500 m

10 deep dives.

11 Glider users have been organized, mostly at an opportunistic level, for more than a decade in 12 international groups (e.g. Everyone's Gliding Observatories (EGO; http://www.ego13 network.org)), as well as national consortia (U.S. IOOS), or as part of larger scale, centralized 14 national ocean observing infrastructure (e.g. Australia's ocean glider facility as part of IMOS). The achieved coordination within the glider user community, in coordination with other groups such as the Argo data expert group, has established a "standardized" data flow and data quality control mechanisms for operational use. As a consequence, glider data are routinely aggregated in DACs such as e.g. Coriolis Data Centre, Integrated Ocean Observing System US-IOOS and Australian IMOS ocean portal. In principle it is possible to make glider data freely available for everyone as it is for Argo and GDP now, and many glider groups already transmit data in near-real-time on the GTS for immediate availability for data assimilation models used by weather forecasting centres and navies.

Currently the world wide largest fleet of autonomous unmanned systems, including ocean gliders, is managed by the GOC at the NAVOCEANO. The glider data (among other data) is used by ocean modelers to estimate current and forecast future environmental ocean conditions. NAVOCEANO then provides these forecasts in near-real time to support strategic, operational, and tactical Navy fleet requirements and activities (Mensi et al. 2014). The GOC glider fleet of $>100$ devices was build up within a couple of years only and which put the technical maturity of the devices to a different level. 


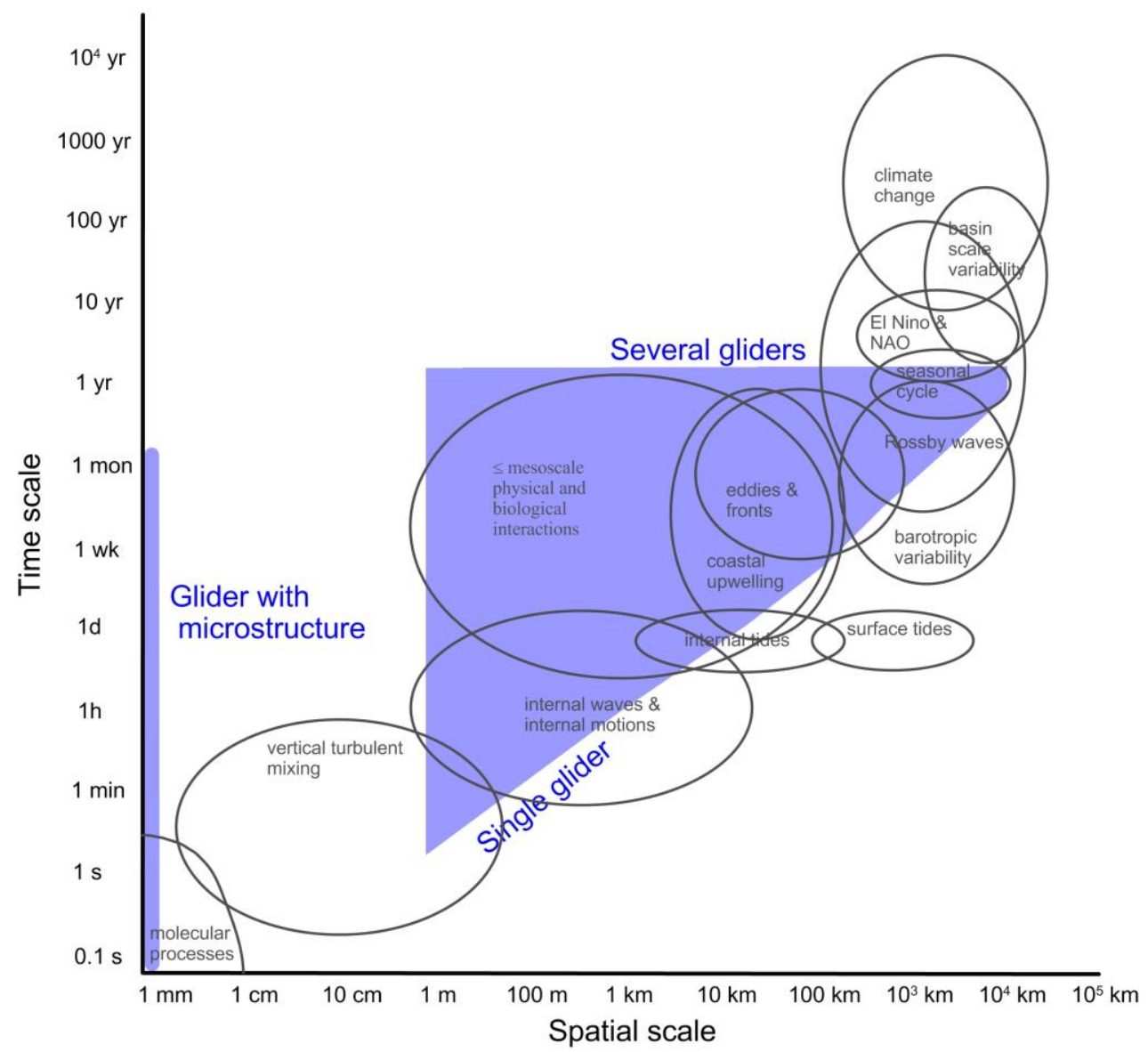

2 Figure 6. As Fig. 2 but for gliders.

3 Early design goals for a global glider network envisioned fleets of manoeuvrable autonomous

4 ships (gliders) that would provide a comprehensive view of the interior ocean in space and

5 time (Stommel 1989). Along with the development of glider technology and applications of

6 gliders in ocean research over the last decade, core scientific applications can be identified

7 (see review in appendix 1) and might fall into the following categories: endurance sections in

8 boundary current regions, surveys of the coastal and open ocean transition zone, surveys of

9 the mesoscale and submesoscale variability, surveys in shallow coastal areas and marginal

10 seas, open ocean surveys in connection with existing (often moored) observatories, surveys of

11 remote regions (e.g. high-latitudes) and in extreme environments (e.g. hurricanes), and

12 surveys that are conducted in the context of hazards (e.g. oil spill). Note that glider data such

13 as temperature, salinity, and dive-averaged currents can be used for model data assimilation

14 for all mentioned categories. 
1 Given the high-resolution vertical sampling and the wide range of sensors to be used on the platform, very successful surveys in frontal regions have revealed submesoscale variability in physical and biogeochemical tracer patterns (e.g., Niewiadomska et al. 2008; Pietri et al. 2013). Depending on the time scales of the governing processes, either single gliders or fleets of gliders are required to minimize the effect of aliasing through the quickly evolving distributions. Before the glider era, research vessels were the only platform that allowed for such mapping (e.g. scanfish surveys).

The ease of deploying gliders from coastal areas allowed endurance line applications over several cross-shelf lines and endurance lines at chokepoints in the ocean that have been operational over several years, e.g. in the California Current System (e.g. Ohman et al. 2013), Mid-Atlantic Bight (Castelao et al. 2010), Rockall Trough (Holliday and Cunningham 2013), Oregon coast (Piero et al. 2014), Western Mediterranean (Heslop et al. 2012) and Eastern Mediterrranean (Hayes et al. 2014). Moreover, the boundary regions hosts intense frontal zones where complex biophysical interaction take place and where the various sensors that can be operated on glider show it full potential.

It has been shown that severe weather conditions, such as hurricanes, do not impact the operations of gliders (e.g. Glenn et al. 2008). Moreover, they can also operate in remote locations that are difficult to access by ships. For example gliders were deployed from the edge of the sea ice into the Ross Sea polynya, enabling study of the initialisation of the spring bloom (Queste et al. 2012, Kaufman et al. 2014). Under ice operations are still very limited for gliders, though feasible to some extent (Beszczynska-Möller et al. 2011).

For specific applications a glider can be "switched" to the sampling characteristics of other observing platforms. Programming the glider to drift with currents resembles an Argo float or a drifter. Commanding a glider to continuously return to one waypoint provides data that resembles a virtual mooring/profiler. Such flight configurations are for example used for the gliders operated in the OOI. OOI manages gliders for science as part of their regional and global nodes ocean observing strategy. Given the typical service interval of 1 year for the OOI nodes, glider operations are optimized for long mission with extended drift periods (at depth). It is noteworthy that glider in OOI also operate as data shuttles, retrieving data via acoustic modem communication from moored device. The data is provided in near real-time and accessible via the OOI website (after registration). 
Table 1. Measurement characteristics of various parameters in different platforms: Horizontal resolution (dx), horizontal range (xr), vertical resolution $(d z)$, vertical range ( $z r)$, measurement interval of sensor (sensor $d t$ ) and measurement repeat time (repeat dt). For the global arrays, such are Argo and drifters, dx implies resolution for both horizontal dimensions while for the XBT and TSG lines horizontal dimension can be determined only for the one dimension (along track). Repeat time is defined as the time interval between two measurements in processed data (surface drifters, moorings, satellites), the time interval between two profiles (Argo, lower limit in research vessels and gliders), the repeat time of section crossings (TSGs, XBTs, research vessels and gliders). Currents are not measured directly by gliders in most cases, but are derived from drift, as in surface drifters and Argo.

\begin{tabular}{|c|c|c|c|c|c|c|c|c|}
\hline Platform & $\mathrm{dx}$ & $\mathrm{xr}$ & $\mathrm{dz}$ & $\mathrm{zr}$ & $\mathrm{dt}$ & $\operatorname{tr}$ & $\begin{array}{l}\text { Standard } \\
\text { payload }\end{array}$ & Additional sensors \\
\hline Argo & $300 \mathrm{~km}$ & $\begin{array}{l}\text { Global, except high } \\
\text { latitudes }\end{array}$ & $\begin{array}{l}5-50 \\
m\end{array}$ & $0-2 \mathrm{~km}$ & $1 \mathrm{~s}$ & 10 days & $\begin{array}{l}\mathrm{P}, \mathrm{T}, \mathrm{C}, \text { mean } \\
\text { current }\end{array}$ & DO, optics \\
\hline Drifters & $500 \mathrm{~km}$ & $\begin{array}{l}\text { Global, except high } \\
\text { latitudes }\end{array}$ & - & $15 \mathrm{~m}$ & $\begin{array}{l}1-2 \\
\text { minutes }\end{array}$ & 6 hours & $\mathrm{T}$, currents & SLP, C \\
\hline TSG & $\begin{array}{l}150 \mathrm{~m} \\
-3 \mathrm{~km}\end{array}$ & Certain routes & - & $5 \mathrm{~m}$ & $\begin{array}{l}1 \mathrm{~s}-1 \\
\min \end{array}$ & $\begin{array}{l}12 \text { hours } \\
-3 \\
\text { months }\end{array}$ & $\mathrm{T}, \mathrm{C}$ & $\begin{array}{l}\text { DO, optics, current } \\
\text { profiles, nutrients }\end{array}$ \\
\hline XBT & $\begin{array}{l}25- \\
200 \mathrm{~km}\end{array}$ & Certain routes & $10 \mathrm{~m}$ & $1-750 \mathrm{~m}$ & $0.1 \mathrm{~s}$ & $\begin{array}{l}\text { 3-12 } \\
\text { weeks }\end{array}$ & $\mathrm{T}$ & - \\
\hline $\mathrm{R} / \mathrm{Vs}$ & $\begin{array}{l}1-100 \\
\mathrm{~km}\end{array}$ & $\begin{array}{l}\text { Certain routes (GO- } \\
\text { SHIP and national } \\
\text { monitoring), otherwise } \\
\text { survey specific }\end{array}$ & $1 \mathrm{~m}$ & full depth & $\begin{array}{l}0.0005 \\
\mathrm{~s}-1 \mathrm{~s}\end{array}$ & $\begin{array}{l}5 \text { min }-1 \\
\text { decade }\end{array}$ & $\begin{array}{l}\text { All, but } \\
\text { depends on } \\
\text { survey }\end{array}$ & All, but depends on survey \\
\hline Moorings & $\begin{array}{l}50 \mathrm{~km} \\
-500 \\
\mathrm{~km}\end{array}$ & Selected areas & $\begin{array}{l}1-1000 \\
m\end{array}$ & $\begin{array}{l}\text { Full depth, } \\
\text { except deepest } \\
\text { trenches }\end{array}$ & $\begin{array}{l}1 \mathrm{~s}-1 \\
\min \end{array}$ & $\begin{array}{l}10 \text { min-1 } \\
\text { day }\end{array}$ & $\begin{array}{l}\text { P, T, C, } \\
\text { DO, optics, } \\
\text { currents }\end{array}$ & Nutrients, radioactivity \\
\hline Gliders & $\begin{array}{l}100 \mathrm{~m}- \\
8 \mathrm{~km}\end{array}$ & Survey specific & $1 \mathrm{~m}$ & $0-1500 \mathrm{~m}$ & $1-5 \mathrm{~s}$ & $\begin{array}{l}5 \text { min-1 } \\
\text { year }\end{array}$ & $\begin{array}{l}\mathrm{P}, \mathrm{T}, \mathrm{C}, \\
\text { mean } \\
\text { current }\end{array}$ & $\begin{array}{l}\text { DO, optics, current } \\
\text { profiles, other acoustics, } \\
\text { nutrients, turbulence }\end{array}$ \\
\hline
\end{tabular}




\section{3. Potential role of gliders in GOOS}

2 GOOS aims to ensure that critical data are collected to generate the relevant ocean

3 information for science and society. Given the wide range of scales and processes that impact

4 the multiple disciplines with interest in the oceans, only a combination of various observing

5 platforms with individual strengths and limitations can serve the observational needs (Fig. 7).

6 It can be said that GOOS has for basic physical processes (heat content changes, surface flow)

7 an adequate coverage of large scale sampling in the open ocean and away from boundary

8 currents primarily through the success in establishing Argo and GDP. Many parameters

9 at/close to the ocean surface are well monitored by multiple satellite systems (Le Traon et al. 10 2015). 


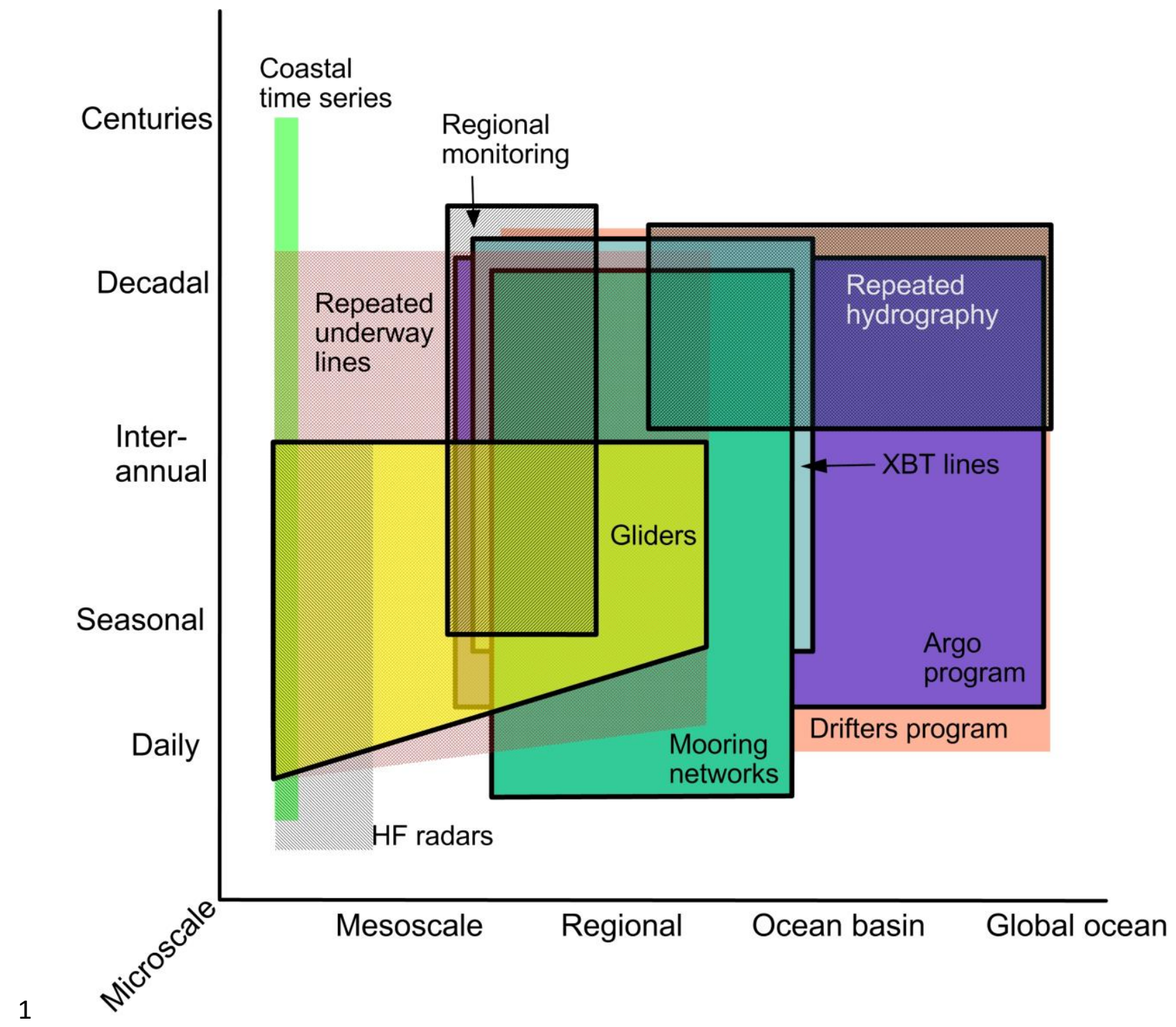

2 Figure 7. Spatial and temporal coverage of various observatories. Horizontal-spatial scales

3 are represented on $x$-axis and temporal scales on $y$-axis. Systems that acquire vertical profiles

4 are surrounded by black bold lines. As in Figures2-6 the upper limits are defined as length of 5 time series of each platform.

6

7 Coastal areas are in some cases well monitored by national agencies (especially in the 8 northern hemisphere) and often also in a sustained way. Coastal observations typically 9 include research vessel visits ("regional monitoring" in Fig. 7), time-series in coastal stations, 10 ferries, offering VOOS services (FerryBox), are a well established observing platform in 11 European coastal seas (Hydes et al. 2010). 
1 However, for the coastal/open ocean transition the situation looks different, and observing 2 efforts decrease dramatically. This may related to the fact that it is also a transition between 3 the international patronage of GOOS and national observing priorities in the coastal areas. On

4 the other hand the obvious impact of propagating anomalies from the open ocean into the 5 coastal areas exists (storm surges, tsunami waves, temperature anomalies, nutrient 6 injections/oxygen decrease) and can have substantial impact on societies and economy. The 7 transition zone, which hosts boundary currents, upwelling/ downwelling regions, physical-, 8 biogeochemical- and biological fronts, is very rich in phenomena and consequently requires a 9 high resolution and multidisciplinary mapping. Gliders do resolve the (sub)mesoscale in two 10 spatial dimensions (along track and vertical) and for multiple parameters. As such they are

11 ideal devices to map the coastal/open ocean transition subsurface structures.

12 Observational data for providing services (e.g. maps, boundary conditions) are expected from 13 the coastal/open ocean transition and daily or even more frequent real-time data access is required (Legler et al. 2015). Drifters, moorings, SOOP/VOS, marine mammals, coastal time series, HF radars and gliders do provide this service. However, if vertical profiles are to be collected at targeted positions over extended periods of time, only moorings and gliders do that autonomously.

Regional expectations for the use of gliders as sustained observing platforms have been outlined by several earlier studies, for example in polar regions (Lee et al. 2010; Rintoul Speer et al. 2010; Abrahamsen 2014) or in boundary current regions (Send et al. 2010).

21 Moreover, sustained use of gliders would enhance the present observatories in respect to monitoring global deep ocean circulation (Garzoli et al. 2010; Rintoul Balmesada et al. 2010), heat content (Palmer et al. 2010), air-sea fluxes (Gulev et al. 2010) and harmful algal blooms

24 (Stumpf et al. 2010). 


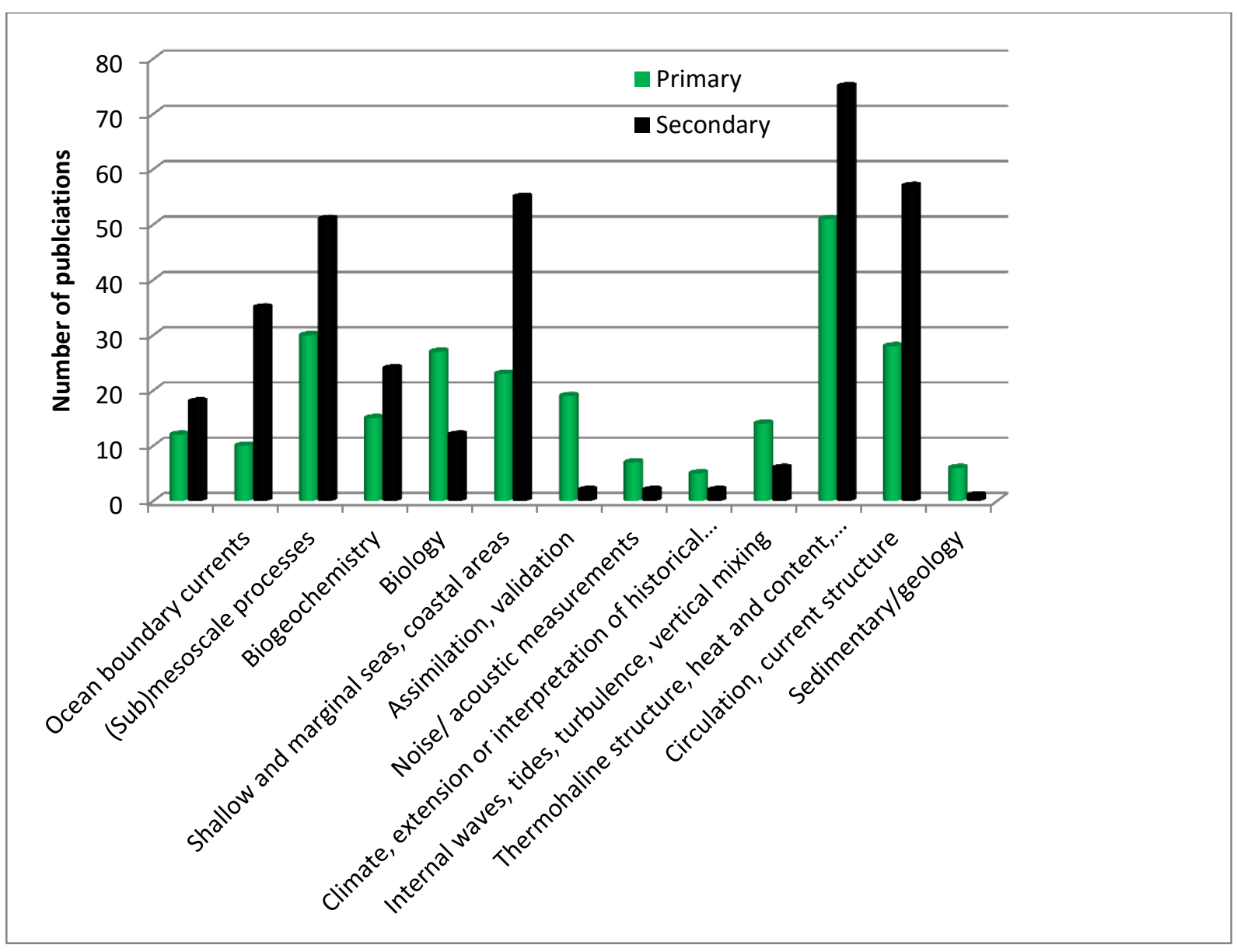

2 Figure 8. Primary and secondary objectives of 140 arbitrarily selected glider publications.

3 (See further details in Appendix 1)

4 We performed a review of arbitrarily selected glider publications (Appendix 1) extracted primary and secondary mission objectives (Fig. 8). This review revealed that gliders are commonly applied concurrently with other measurement platforms. The highest synergy appears to be with satellite remote sensing (focussing on subsurface analysis of (sub)mesoscale processes), research vessels and moored platforms. In coastal regions gliders have been used in joint analysis with HF radar surface current. The most frequent use of glider data is in the context of hydrography and current structure analysis. Many studies are related to combining physical with biogeochemical and biological data (Fig. 8).

Thus physical-biogeochemical-biological interaction in meso- and submesoscale is one of the key topics in which gliders will contribute considerably to the GOOS and ocean science in general. Another future niche of gliders could be acoustic measurements in the ocean (e.g. Baumgartner and Fratantoni 2008; Klinck et al. 2012) as well as data shuttle functions. 

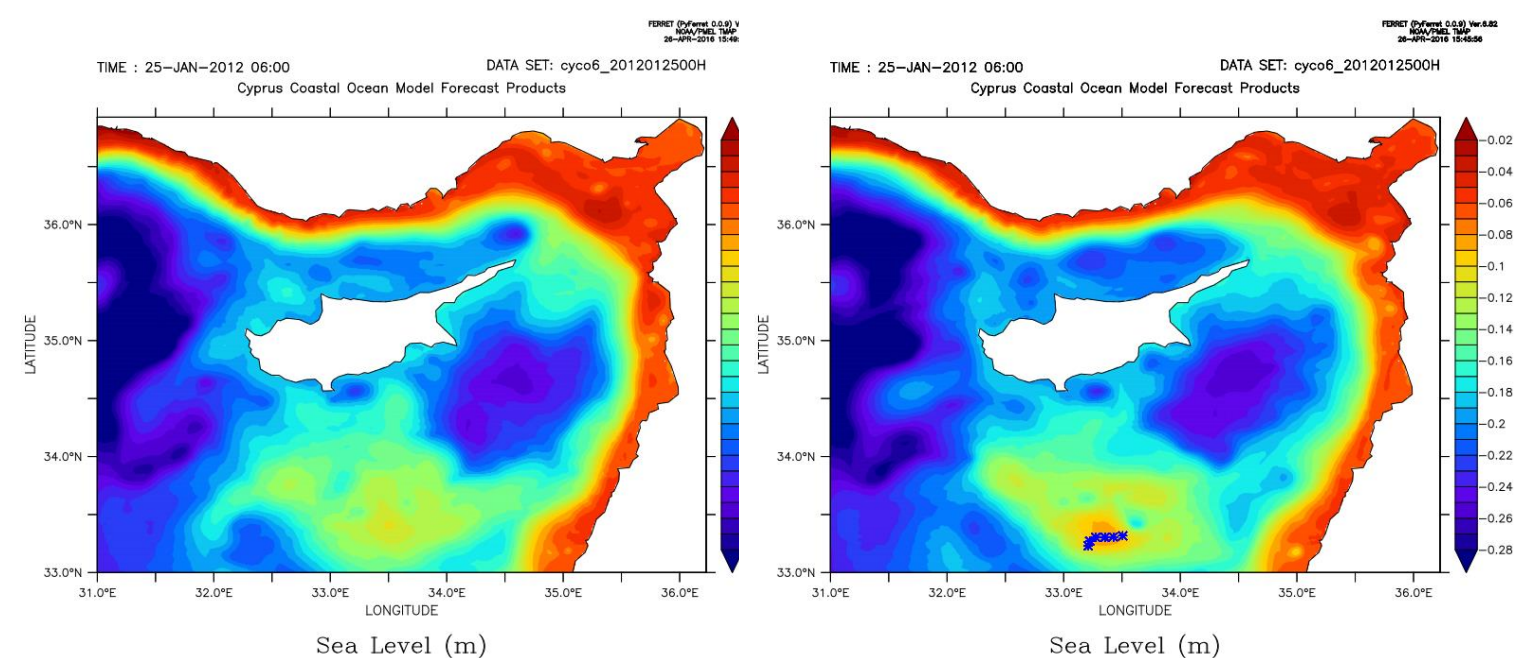

3 Figure 9. The sea surface height on 2012-01-24 from an experiment using the operational

4 Cyprus Coastal Ocean Model: (right) assimilating glider temperature and salinity profiles

5 daily, and (left) no assimilation. Glider profiles on the respective day are marked as blue

6 points in the area between $33.0-33.5^{\circ} \mathrm{E}$ and $33.0-33.5^{\circ} \mathrm{N}$.

7 Several studies have shown that assimilation of glider-acquired data enhances simulation performance. Gliders can be an effective operational tool for monitoring different processes (including hazards), either independently or in conjunction with numerical modelling and/or remote sensing. Moreover the transition of ocean forecast models and reanalysis systems towards higher resolution requires high resolution in-situ sampling. Gliders might be the only autonomously operated in-situ platform that can resolve the vertical dimension at the necessary lateral scale.

An example of how gliders can improve mesoscale forecast accuracy is shown in Fig. 9. This shows the effect of operational data assimilation of temperature and salinity profiles from a single glider on the predicted sea surface height compared to a control run. In this experiment, the Cyprus Coastal Ocean Model was run daily with the OceanVar (Dobricic and Pinardi 2008) using 2 day hindcasts, and at the same time a control run was forced with the same open and surface boundary conditions, both initialized from a coarse model in early December 2011 (just before the glider mission began). A higher sea surface height is seen in the region of observations in this case, because a warm sub-surface core in that area was detected (the well-known Cyprus eddy). 
1 Besides delivering data that are used in operational models, alerts can be sent when patrolling areas to detect natural (toxic blooms) or anthropogenic driven (mining, dredging, oil spill) hazards. A good example is the use of gliders (among other platforms) to track the Gulf of Mexico oil spill (Lubchenco et al. 2012).

So far, gliders have been used in operations that contribute to the social benefit areas that have been worked out as part of GOOS strategic mapping (http://lists-ioc-goos.org/strategicmapping/) and include efficient maritime economy, coastal protection, carbon storage, human health, clean waters, coastal livelihoods, tourism/cultural and food security, climate services, and mitigation of climate change.

The reliability of gliders still needs improvement. For instance the probability of a deep water glider surviving a 90-day mission is approximately 0.5 (Brito et al. 2014). The safe operation of gliders in areas with intensive marine traffic has been questioned in the past. However, glider missions that constantly adjusted their navigation guided by the information from realtime ship traffic monitoring (e.g. via Automatic Identification System, AIS) have successfully been tested and planning software has been developed to minimize this risk (L. Merckelbach, personal communication). Gliders may encounter problems when navigating in regions of strong currents and sophisticated missions planning is required. Specific software that is currently developed, can generate mission plans that take advantage of these currents to visit regions of high uncertainty (D. Hayes, personal communication).

The legal status of glider surveys has been analysed (Bork et al. 2008; Hofmann and Proelss, 2015) including the options for defining the glider vehicle as a hybrid of a surface manoeuvrable and drifting (strong currents) device. Technically, a glider is likely to be classified as SRE (Scientific Research Equipment) carrying out MSR (Marine Scientific Research). In this framework, it is generally "necessary to seek the consent of foreign coastal States for the deployment and use of a glider within the maritime zones under the jurisdiction of these states" (Hofmann and Proelss 2015). 


\section{4. Conclusions}

2 Given the ability of gliders to survey a specific segment of the time/space and parameter

3 domain in ocean observing they have become productive and versatile survey platforms in 4 oceanography. This could be evaluated by analysing the primary and secondary mission objectives from a set of 140 arbitrarily selected glider publications. The specific strengths of a sustained glider component in GOOS include:

- the provision of observational data at a resolution that bridge spatial, temporal, and parameter sampling gaps that exist in the present day GOOS in particular for the socially relevant coastal/open ocean transition zone and boundary currents

- the ability of gliders to carry a variety of sensors and to acquire data of relevance for the future challenges of GOOS to include essential biogeochemical, biological and ecosystem variables

- the operational monitoring of natural hazards like toxic blooms, and of anthropogenic activities such as those associated with mining, dredging and oil spills

- the ability to provide in-situ profile data that revolves temporal and spatial scales that are of relevance in assessing or improving the skill of the currently emerging highresolution ocean forecast models, ultimately improving operational safety of marine activities

- the ability to leverage organizational efforts that have been undertaken over the last decade to establish a globally coordinated network of glider operators who have aimed to develop a platform for training, sharing of best practices, software and hardware, as well as for standardization of operation procedures, and data management.

The close collaboration of glider operators, supported by several projects (e.g. EGO-COST Action ES0904; FP7 GROOM), allowed the creation of a well-connected international network. Out of this network, the basic actions, such as formulating an implementation plan, standardizing data protocols and data transmissions, are under preparation. A full implementation of a sustained glider component in GOOS has been initiated via the World Meteorological Organization (WMO) and UNESCO's Intergovernmental Oceanographic 
1 Commission (IOC) Joint Technical Commission for Oceanography and Marine Meteorology

2 in-situ Observing Platform Support Centre (JCOMMOPS).

3 We identify two particular challenges for the global glider network: first is capacity building,

4 including glider mission planning and execution as well as training in using glider data. The

5 second is the coordinated planning and execution of multinational missions in a sustained

6 mode. To address the second issue, a coordinated pilot action could be aimed for, e.g. on

7 studies in the coastal/open ocean transition zone and embedded in existing observing projects

8 such as CLIVAR (www.clivar.org). Only overcoming these challenges will ensure a truly

9 global expansion of glider use for the benefit of a variety of societal and scientific areas.

\section{Acknowledgements}

12 Comments from two anonymous reviewers and the Associate Editor G. Griffiths are

13 appreciated. This work was supported by the European Union 7th Framework Programme

14 (FP7 2007-2013), under grant agreement number 284321 GROOM (www.groom-fp7.eu); and

15 the European Union's Horizon 2020 Research and Innovation Programme under grant

16 agreement number 633211 AtlantOS.

18 REFERENCES

Abrahamsen EP. 2014. Sustaining observations in the polar oceans. Philosophical Transactions of the Royal Society a-Mathematical Physical and Engineering Sciences $372,2025$.

23 Argo Science Team. 1998. On the design and implementation of Argo: an initial plan for a global array of profiling floats. International CLIVAR Project Office Report 21. 
GODAE Report, vol. 5.GODAE International Project Office, Melbourne, Australia, 32 pp.

Bakker DCE, Pfeil B, Olsen A, Sabine C, Metzl N, Hankin S, Koyuk H, Kozyr A, Malczyk J, Manke A, Telszewski M. 2012. Global data products help assess changes to the ocean carbon sink. Eos, Transactions of the American Geophysical Union 93(12): 125-126.

Baumgartner M, Fratantoni D. 2008. Diel periodicity in both sei whale vocalization rates and the vertical migration of their copepod prey observed from ocean gliders, Limnol. Oceanogr., 53(5, part 2), 2008, 2151.

Beszczynska-Möller A, Woodgate RA, Lee C, Melling H, and Karcher M. 2011. A synthesis of exchanges through the main oceanic gateways to the Arctic Ocean. Oceanography 24(3):82-99, Available from: http://dx.doi.org/10.5670/oceanog.2011.59.

Bork K, Karstensen J, Visbeck M, Zimmermann A. 2008. The Legal Regulation of Floats and Gliders- In Quest of a New Regime? Ocean Developpment \& international law, 39: 298-328.

Breivik O, Allen AA, Maisondieu C, Olagnon M. 2013. Advances in search and rescue at sea. Ocean Dynamics, 63 (1), 83-88.

Brito M, Smeed D, Griffiths G. 2014. Underwater glider reliability and implications for survey design. /Journal of Atmospheric and Oceanic Technology/, /31/(12), 28582870.

Castelao R, Glenn S, and Schofield O. 2010.Temperature, salinity, and density variability in the central Middle Atlantic Bight, J. Geophys. Res.,115, C10005, doi:10.1029/2009JC006082.

Dobricic, S and Pinardi N. 2008. An oceanographic three-dimensional variational data assimilation scheme. Ocean Modelling, 22 (3-4), 89-105.

Durack, P. J., Lee, T., Vinogradova, N. T., \& Stammer, D. (2016). Keeping the lights on for global ocean salinity observation. /Nature Climate Change/, /6/(3), 228-231.

Fedak MA, 2013. The impact of animal platforms on polar ocean observation. Deep-Sea Res. II 88-89, 7-13.

Feely, RC, Cosca C, Alin S and Lebon G. 2012. Sea Surface and Atmospheric fCO2 measurements in the Pacific Ocean during VOS project line onboard the M/S Natalie Schulte. http://cdiac.ornl.gov/ftp/oceans/VOS_Natalie_Schulte_Lines/. Carbon Dioxide Information Analysis Center, Oak Ridge National Laboratory, US 
Department of Energy, Oak Ridge, Tennessee. doi:10.3334/CDIAC/OTG.VOS_NATALIE_SCHULTE_LINES

Fer I, Peterson AK and Ullgren JE. 2014. Microstructure Measurements from an Underwater Glider in the Turbulent Faroe Bank Channel Overflow. Journal of Atmospheric and Oceanic Technology, 31, 1128-1150.

Garzoli SL, Boebel O, Bryden H, Fine RA, Fukasawa M, Gladyshev S, Johnson G, Johnson M, MacDonald A, Meinen C, et al. 2010. Progressing Towards Global Sustained Deep Ocean Observations. Proceedings of OceanObs'09: Sustained Ocean Observations and Information for Society (Vol. 2), Venice, Italy, 21-25 September 2009, Hall, J., Harrison, D.E. \& Stammer, D., Eds., ESA Publication WPP-306, doi:10.5270/OceanObs09.cwp.34

Glenn S, Jones C, Twardowski M, Bowers L, Kerfoot J, Kohut J, Webb D, Schofield O. 2008. Glider observations of sediment resuspension in a Middle Atlantic Bight fall transition storm. Limnol.Oceanogr., 53 (5, part 2), 2180-2196.

Goni G, Roemmich D, Molinari R, Meyers G, Sun C, Boyer T, Baringer M, Gouretski V, DiNezio P, Reseghetti F, et al. 2010. The Ship of Opportunity Program. Proceedings of OceanObs'09: Sustained Ocean Observations and Information for Society (Vol. 2), Venice, Italy, 21-25 September 2009, Hall, J., Harrison, D.E. \& Stammer, D., Eds., ESA Publication WPP-306, doi:10.5270/OceanObs09.cwp.35.

Gruber N, Doney SC, Emerson SR, Gilbert D, Kobayashi T, Körtzinger A, Johnson GC, Johnson KS, Riser SC, Ulloa O. 2010. Adding Oxygen to Argo: Developing a Global In Situ Observatory for Ocean Deoxygenation and Biogeochemistry. Proceedings of OceanObs'09: Sustained Ocean Observations and Information for Society (Vol. 2), Venice, Italy, 21-25 September 2009, Hall, J., Harrison, D.E. \& Stammer, D., Eds., ESA Publication WPP-306, doi:10.5270/OceanObs09.cwp.39

GROOM 2014. Deliverable 5.7. Report describing costs to build and operate the glider observatory infrastructure. Available from: http://www.groomfp7.eu/lib/exe/fetch.php?media=public:deliverables:groom_d5.7_cnrs.pdf

GROOM 2015. Deliverable 5.2. Sensors for gliders: existing, under development, and future sensors. Available from: http://www.groomfp7.eu/lib/exe/fetch.php?media=public:deliverables:groom_d5.2_ucy_rev.pdf 
Gulev SK, Josey SA, Bourassa M, Breivik L-A, Cronin MF, Fairall C, Gille S, Kent EC, Lee CM, McPhaden MJ, et al. 2010. Surface Energy, CO2 Fluxes and Sea Ice. Proceedings of OceanObs'09: Sustained Ocean Observations and Information for Society (Vol. 1), Venice, Italy, 21-25 September 2009, Hall, J., Harrison, D.E. \& Stammer, D., Eds., ESA Publication WPP-306, doi:10.5270/OceanObs09.pp.19

Hayes D, Hannides A, Testor P, Gildor H, Zodiatis G, Georgiou G. 2014. Description of the Long-lived Subsurface Mesoscale Eddy South of Cyprus. $6^{\text {th }}$ EGO Meeting 16-17 June, Kiel, Germany.

Hernandez O, Boutin J, Kolodziejczyk N, Reverdin G, Martin N, Gaillard F, Reul N, Vergely JL. 2014. SMOS salinity in the subtropical North Atlantic salinity maximum: 1. Comparison with Aquarius and in situ salinity, J. Geophys. Res. Oceans, 119, 88788896.

Heslop E, Ruiz ES, Allen J, López-Jurado JL, Renault L, Tintoré J. 2012. Autonomous underwater gliders monitoring variability at choke points" in our ocean system: A case study in the Western Mediterranean Sea, Geophys. Res. Lett., 39, L20604, doi:10.1029/2012GL053717.

Hofmann T, Proelss A. 2015. The Operation of Gliders Under the International Law of the Sea. Ocean Development \& International Law, 46(3), 167-187.

Holliday NP, Cunningham SA. 2013.The Extended Ellett Line Discoveries from 65 Years of Marine Observations West of the UK. Oceanography 26(2): 156-163.

Hood M, Fukasawa M, Gruber N, Johnson G, Koertzinger A, Sabine C, Sloyan B, Stansfield K, Tanhua T. 2010. Ship-Based Repeat Hydrography: A Strategy for a Sustained Global Program. Proceedings of OceanObs'09: Sustained Ocean Observations and Information for Society (Vol. 2), Venice, Italy, 21-25 September 2009, Hall, J., Harrison, D.E. \& Stammer, D., Eds., ESA Publication WPP-306, doi:10.5270/OceanObs09.cwp.44

Houghton J, Townshend J, Dawson K, Mason P, Zillmann J, Simmons A. 2012. The GOOS at 20 years, the origin achievement and future development of the Global Climate Observing System, Weather, 67 (9), doi:10.1002/wea.1964

Hydes DJ, Kelly-Gerreyn B-A, Colijn F, Petersen W, Schroeder F, Mills DK, Durand D, Wehde H, Sörensen K, Morrison G. 2010. The Way Forward in Developing and Integrating Ferrybox Technologies. Proceedings of OceanObs'09: Sustained Ocean 
Observations and Information for Society (Vol. 2), Venice, Italy, 21-25 September 2009, Hall, J., Harrison, D.E. \& Stammer, D., Eds., ESA Publication WPP-306, doi:10.5270/OceanObs09.cwp.46

Kaufman DE, Friedrichs MAM, Smith Jr. WO, Heywood KJ, Queste BY. 2014. Biogeochemical Variability in the Southern Ross Sea as observed by a Glider Deployment, Deep-Sea Research I, 92, 93-106. DOI: 10.1016/j.dsr.2014.06.011.

Keeley R, Pazos M, Bradshaw B. 2010. Data Management System for Surface Drifters. Proceedings of OceanObs'09: Sustained Ocean Observations and Information for Society (Vol. 2), Venice, Italy, 21-25 September 2009, Hall, J., Harrison, D.E. \& Stammer, D., Eds., ESA Publication WPP-306, doi:10.5270/OceanObs09.cwp.47

Kent EC, Ball G, Berry DI, Fletcher J, Hall A, North S, Woodruff S. 2010. The Voluntary Observing Ship (VOS) Scheme. Proceedings of OceanObs'09: Sustained Ocean Observations and Information for Society (Vol. 2), Venice, Italy, 21-25 September 2009, Hall, J., Harrison, D.E. \& Stammer, D., Eds., ESA Publication WPP-306, doi:10.5270/OceanObs09.cwp.48

Kessler W, Cravatte S. 2013. Mean circulation of the Coral Sea. J. Geophys. Res. Oceans, 118, pp. 6385-6410. Available from: http://dx.doi.org/10.1002/2013JC009117.

Klatt O, Boebel O, Fahrbach E. 2007. A Profiling Float's Sense of Ice. J. Atmos. Oceanic Technol., 24, 1301-1308. Available from: http://dx.doi.org/10.1175/JTECH2026.1

Klinck H, Mellinger, DK, Klinck K, Bogue NM, Luby JC, Jump WA, Shilling GB, Litchendorf T, Wood AS, Schorr GS, Baird RW. 2012. Near-real-time acoustic monitoring of beaked whales and other cetaceans using a SeagliderTM. PLoS ONE 7, e36128. doi:10.1371/journal.pone.0036128

Lee GM, Melling H, Eicken H, Schlosser P, Gascard J-C, Proshutinsky A, Fahrbach E, Mauritzen C, Morison J, Polykov I. 2010. Autonomous Platforms in the Arctic Observing Network" in Proceedings of OceanObs'09: Sustained Ocean Observations and Information for Society (Vol. 2), Venice, Italy, 21-25 September 2009, Hall, J., Harrison, D.E. \& Stammer, D., Eds., ESA Publication WPP-306, doi:10.5270/OceanObs09.cwp.54

Legler DM, Freeland HJ, Lumpkin R, Ball G, McPhaden MJ, North S, Crowley R, Goni GJ, Send U, Merrifield MA. 2015. The current status of the real-time in situ Global Ocean Observing System for operational oceanography, Journal of Operational 


\section{DOI:10.1080/1755876X.2015.1049883}

Le Traon P-Y, Antoine D, Bentamy A, Bonekamp H, Breivik LA, Chapron B, Corlett G , Dibarboure G, DiGiacomo P, Donlon C, et al. 2015. Use of satellite observations for operational oceanography: recent achievements and future prospects, Journal of Operational Oceanography, 8:sup1, s12-s27, DOI: 10.1080/1755876X.2015.1022050

Leppäranta M, Zhanhai Z, Haapala J, Stipa T, 2001. Sea-ice kinematics measured with GPS drifters. Annals of Glaciology 33, 151-156.

Lindstrom E. A framework for ocean observing. Available from: http://dx.doi.org/10.5270/OceanObs09-FOO (UNESCO)

Lubchenco J, McNutt MK, Dreyfus G, Murawski SA, Kennedy DM, Anastas PT, Chu S, Hunter T. 2012. Science in support of the Deepwater Horizon response. Proceedings of the National Academy of Sciences: 109, 20212-20221.

Lips U, Lips I, Liblik T, Kikas V, Altoja K, Buhhalko N, Rünk N. 2011.Vertical dynamics of summer phytoplankton in a stratified estuary (Gulf of Finland, Baltic Sea). Ocean Dynamics, 61, 903 - 915.

Lumpkin R, King B. 2008. Report on the $1^{\text {st }}$ CLIVAR Global Synthesis and Observation Panel Workshop on Ocean Velocity Measurements and their Application. WRCP Informal Report No.

5/2008.http://www.clivar.org/sites/default/files/documents/129_GSOP_Workshop_0.p $\underline{\mathrm{df}}$

Lumpkin, R, L Centurioni, RC Perez, 2016. Fulfilling Observing System Implementation $\underline{\text { Requirements with the Global Drifter Array. Journal of Atmospheric and Oceanic }}$ Technology 33:4, 685-695, doi:10.1175/2008BAMS2577.1

Mensi B., Rowe R, Dees S, Bryant D, Jones D and Carr R. Operational glider monitoring, piloting, and communications. 2014 IEEE/OES Autonomous Underwater Vehicles (AUV), Oxford, MS, 2014, pp. 1-3. doi: 10.1109/AUV.2014.7054415.

Niewiadomska K, Claustre H, Prieur L, d'Ortenzio F, 2008. Submesoscale physicalbiogeochemical coupling across the Ligurian Current (northwestern Mediterranean) using a bio-optcal glider, Limnology and Oceanography, 53, 2210-2225.

Ohman MD, Rudnick DL, Chekalyuk A, Davis RE, Feely RA, Kahru M, Kim H-J, Landry MR, Martz TR, Sabine CL, Send U. 2013. Autonomous ocean measurements in the 
California Current Ecosystem. Oceanography 26(3):18-25, http://dx.doi.org/10.5670/oceanog.2013.41.

Palmer MD, Antonov J, Barker P, Bindoff N, Boyer T, Carson M, Domingues C, Gille S, Gleckler P, Good S, et al. 2010. Future Observations for Monitoring Global Ocean Heat Content. Proceedings of OceanObs'09: Sustained Ocean Observations and Information for Society (Vol. 2), Venice, Italy, 21-25 September 2009, Hall, J., Harrison, D.E. \& Stammer, D., Eds., ESA Publication WPP-306, doi:10.5270/OceanObs09.cwp.68

Piero L, Mazzini F, Barth JA, Shearman RK, and Erofeev A, 2014. Buoyancy-Driven Coastal Currents off Oregon during fall and winter. J. Phys. Oceanogr., 44, 2854-2876. doi: http://dx.doi.org/10.1175/JPO-D-14-0012.1

Pietri A, Testor P, Echevin V, Chaigneau A, Mortier L, Eldin G, Grados C. 2013. Fine scale vertical structure of the upwelling system of Southern Peru as observed from glider data. J. Phys. Oceanogr., 43, 631-646.

Purokoski T, Aro E, Nummelin A. 2013.First long-term deployment of Argo float in the Baltic Sea. Sea Technology, 54(10), 41-44.

Queste BY, Heywood KJ, Kaiser J, Lee GA, Matthews A, Schmidtko S, Walker-Brown C, Woodward SW. 2012. Deployments in extreme conditions: Pushing the boundaries of Seaglider capabilities. In 2012 IEEE/OES Autonomous Underwater Vehicles (AUV) (pp. 1-7).IEEE. doi:10.1109/AUV.2012.6380740.

Rantajärvi E (ed.). 2003. Alg@line in 2003: 10 years of innovative plankton monitoring and research and operational information service in the Baltic Sea - Meri - Report Series of the Finnish Institute of Marine Research No. 48. - 55 p.

Reid PC, Bathman U, Batten SD, Brainard RE, Burkill PH, Carlotti F, Chiba S, Conversi A, Dickson RR, Dooley H. 2010. A Global Continuous Plankton Recorder Programme. Proceedings of OceanObs'09: Sustained Ocean Observations and Information for Society (Vol. 2), Venice, Italy, 21-25 September 2009, Hall, J., Harrison, D.E. \& Stammer, D., Eds., ESA Publication WPP-306, doi:10.5270/OceanObs09.cwp.73 Renaud P. 2003. Oceanographic information superiority through battlespace characterization. Sea Technology, 44 (12), 7-7.

Rintoul SR, Speer K, Sparrow M, Meredith M, Hofmann E, Fahrbach E, Summerhayes C, Worby A, England M, Bellerby R. 2010. Southern Ocean Observing System (SOOS): 
Rationale and Strategy for Sustained Observations of the Southern Ocean. Proceedings of OceanObs'09: Sustained Ocean Observations and Information for Society (Vol.

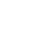
2), Venice, Italy, 21-25 September 2009, Hall, J., Harrison, D.E. \& Stammer, D., Eds., ESA Publication WPP-306, doi:10.5270/OceanObs09.cwp.74

Rintoul SR, Balmesada M, Cunningham S, Dushaw BD, Garzoli S, Gordon AL, Heimbach P, Hood M, Johnson GC, Latif M, et al. 2010. Deep Circulation and Meridional Overturning: Recent Progress and a Strategy for Sustained Observations. Proceedings of OceanObs'09: Sustained Ocean Observations and Information for Society (Vol. 1), Venice, Italy, 21-25 September 2009, Hall, J., Harrison, D.E. \& Stammer, D., Eds., ESA Publication WPP-306, doi:10.5270/OceanObs09.pp.32

Riser, S. C., Freeland, H. J., Roemmich, D., Wijffels, S., Troisi, A., Belbeoch, M., Gilbert, D., Xu, J., Pouliquen, S., Thresher, A., Le Traon, P-Y., Maze, G., Klein, B., Ravichandran, M., Grant, F., Poulain, P-M., Suga, T., Lim, B., Sterl, A., Sutton, P., Mork, K-A., Vélez-Belchí, P. J., Ansorge, I., King, B., Turton, J., Baringer, M. and Jayne, S, 2016. Fifteen years of ocean observations with the global Argo array. Nature Climate Change 6, 145-153, doi: 10.1038/nclimate2872

Roemmich D, Zilberman N, Sutton P, Davis R, Gilson J, Grindley K, Janzen C, Johnson G, Kobayashi T, Larson N, et al. 2014. Development of the Deep Argo Program. Abstract in Ocean Surface Topography meeting, Lake Constance, Germany, 28 October-31 October 2014.

Rossby T, Zhang HM, 2001. The near-surface velocity and potential vorticity structure of the Gulf Stream. Journal of Marine Research 59(6): 949-975.

Rudnick DL. 2015. Ocean research enabled by underwater gliders. Annual Review of Marine Science, 2016.8:9.1-9.23, doi: 10.1146/annurev-marine-122414-033913.

Ruhl HA, Andre M, Beranzoli L, Gagatay MN, Colaco A, Cannat M, Danobeitia JJ, Favali P, Geli L, Gillooly M, et al. 2011.Societal need for improved understanding of climate change, anthropogenic impacts, and geo-hazard warning drive development of ocean observatories in European Seas. Prog.Oceanogr., 91, 1-33.

Schaap DMA, Lowry RK. 2010. SeaDataNet - Pan-European infrastructure for marine and ocean data management: unified access to distributed data sets. Int. Journal Digital Earth, 3, 50-69. 
Sharma N, Brickley P, Owen G, Coholan P. 2010. Use of air-deployed drogued drifting Buoys for oil spill tracking. Oceans-IEEE, Washington State Vongerence and Trade Center, Seattle, WA, Sep 20-23 2010.

Send U, Davis R, Fischer J, Imawaki S, Kessler W, Meinen C, Owens B, Roemmich D, Rossby T, Rudnick D. 2010. A Global Boundary Current Circulation Observing Network" in Proceedings of OceanObs'09: Sustained Ocean Observations and Information for Society (Vol. 2), Venice, Italy, 21-25 September 2009, Hall, J., Harrison, D.E. \& Stammer, D., Eds., ESA Publication WPP-306, doi:10.5270/OceanObs09.cwp.78

Send U, Weller RA, Wallace D, Chavez F, Lampitt RL, Dickey T, Honda M, Nittis K, Lukas R, McPhaden M. 2010. OceanSITES. Proceedings of OceanObs'09: Sustained Ocean Observations and Information for Society (Vol. 2), Venice, Italy, 21-25 September 2009, Hall, J., Harrison, D.E. \& Stammer, D., Eds., ESA Publication WPP-306, doi:10.5270/OceanObs09.cwp.79

Send, U, Fowler G, Siddall G, Beanlands B, Pittman M, Waldmann C, Karstensen J, Lampitt R. 2013. SeaCycler: A moored open-ocean profiling system for the upper ocean in extended self-contained deployments Journal of Atmospheric and Oceanic Technology, 30 (7). pp. 1555-1565. DOI 10.1175/JTECH-D-11-00168.1.

Simonetti P. 1992. Slocum Glider: Design and 1991 Field Trials, Office of Naval Technology Contract N00014-90C-0098 Report, 1992.

Smith SR, Bourassa MA, Bradley EF, Cosca C, Fairall CW, Goni GJ, Gunn JT, Hood M, Jackson DL, Kent EC. 2010. Automated Underway Oceanic and Atmospheric Measurements from Ships” in Proceedings of OceanObs'09: Sustained Ocean Observations and Information for Society (Vol. 2), Venice, Italy, 21-25 September 2009, Hall, J., Harrison, D.E. \& Stammer, D., Eds., ESA Publication WPP-306, doi:10.5270/OceanObs09.cwp.82.

Stommel, H. 1963. The varieties of oceanographic experience. Science 139:572-576.

Stommel H. 1989. The Slocum Mission, Oceanography, April 1989.

Stumpf R, Fleming-Lehtinen V and Granéli E. 2010. Integration of Data for Nowcasting of Harmful Algal Blooms in Proceedings of OceanObs'09: Sustained Ocean Observations and Information for Society (Vol. 1), Venice, Italy, 21-25 September 
2009, Hall, J., Harrison, D.E. \& Stammer, D., Eds., ESA Publication WPP-306, doi:10.5270/OceanObs09.pp.36

Summerhayes C. 2002. Technical tools for regional seas management: the role of the Global Ocean Observing System (GOOS). Ocean \& Coastal Management 45(11-12): 777796.

Sun B, Yu L, Weller RA. 2003. Comparisons of surface meteorology and turbulent heat fluxes over the Atlantic: NWP model analyses versus moored buoy observations. J. Climate, 16, 679-695

Testor P, Meyers G, Pattiaratchi C, Bachmayer R, Hayes D, Pouliquen S, de la Villeon LP, Carval T, Ganachaud A, Gourdeau L. 2010. Gliders as a Component of Future Observing Systems. Proceedings of OceanObs'09: Sustained Ocean Observations and Information for Society (Vol. 2), Venice, Italy, 21-25 September 2009, Hall, J., Harrison, D.E. \& Stammer, D., Eds., ESA Publication WPP-306, doi:10.5270/OceanObs09.cwp.89.

Thompson AF, Heywood KJ, Thorpe SE, Renner AHH and Trasvina A. 2009. Surface circulation at the Tip of the Antarctic Peninsula from Drifters, J. Phys. Oceanogr., 39, $3-26$.

Trtanj JM, Houston, TG. 2014. Climate Variability and Change Data and Information for Global Public Health. Chapter 2 in Pinkerton K. E. and Rom, W.N (editors), Global Climate Change and Public Health, Springer Science+Business Media, New York.

Vranes K, Gordon AL. 2005. Comparison of Indonesian Throughflow transport observations, Makassar Strait to eastern Indian Ocean, Geophys. Res. Lett., 32, L10606, doi:10.1029/2004GL022158.

White WB. 1994. Design a global observing system for gyre-scale upper ocean temperature variability. Prog.Oceanog., 36, 169-217.

Woodworth PL, Player R. 2008. The permanent service for mean sea level: An update to the 21st century. J. Coast Res., 19 (2), 287-295.

Worley SJ, Woodruff SD, Reynolds RW, Lubker SJ, Lott N. 2005. ICOADS release 2.1 data and products. International Journal of Climatology 25(7): 823-842.

Zhang, H.-M., R. W. Reynolds, R. Lumpkin, R. Molinari, K. Arzayus, M. Johnson, and T. M. Smith, 2009: An Integrated Global Ocean Observing System for sea surface 
temperature using satellites and in situ data: Research to operations. Bull. Amer. Meteor. Soc., 90, 31-38, doi:10.1175/2008BAMS2577.1.

3 Zhou S-Q, and Lu Y-Z. 2013. Characterization of double diffusive convection steps and heat 4 budget in the deep Arctic Ocean, J. Geophys. Res. Oceans, 118, 6672-6686, doi:10.1002/2013JC009141. 


\section{Research topics in glider studies and synergy with other} platforms

4 Glider missions have provided a considerable amount of ocean data during the last decade as 5 for example shown from the glider data available via international data centres (Fig. A1).

6 Likewise, the number of scientific studies in which glider data are used has substantially 7 grown. According to Scopus database (scopus.com) 191 papers have been published 8 (abstracts of peer-reviewed articles were searched by term "glider ocean") during the period of 2009-2015. For earlier years (before 2009) the database gives only 28 entries (as of 25April-2016).

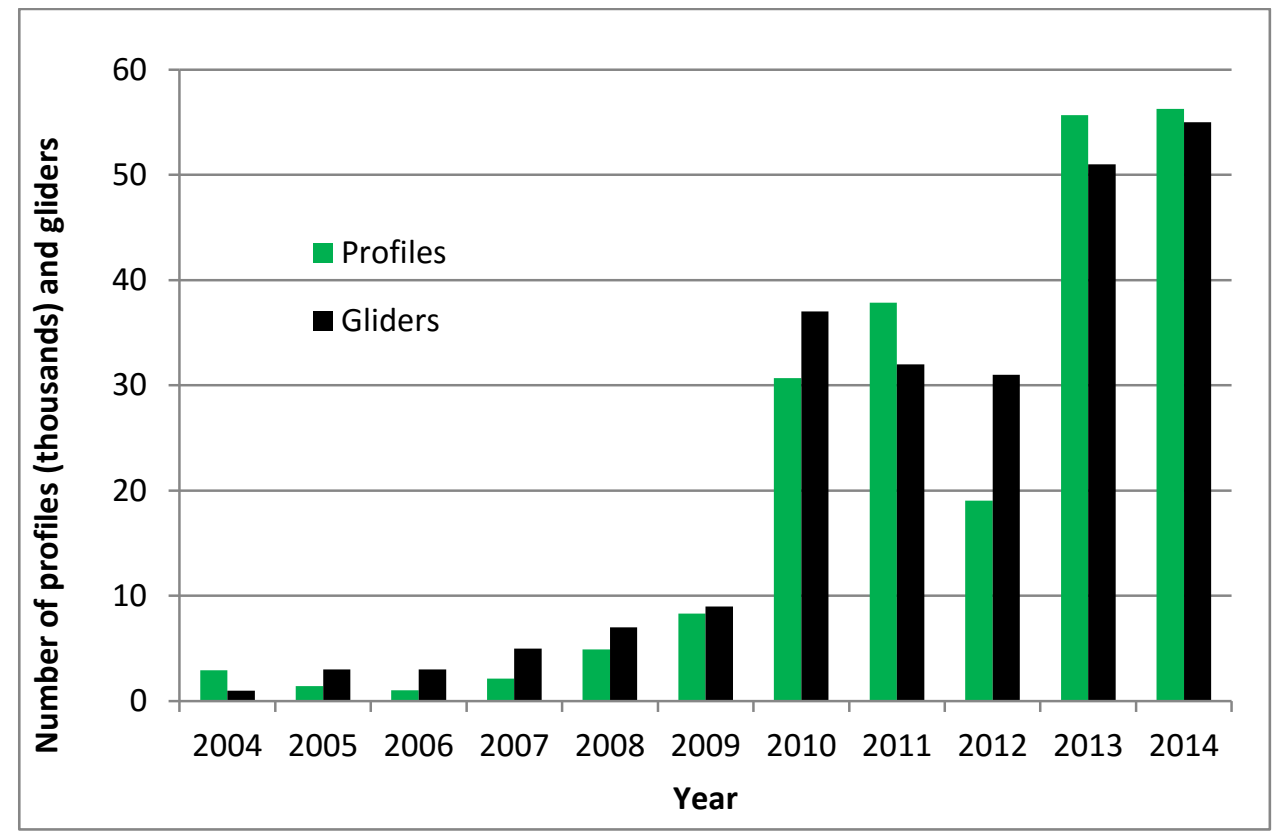

Figure A1. Glider-acquired profiles and number of gliders in Coriolis database (www.coriolis.eu.org).

140 scientific glider papers were randomly selected (from scopus.com) to map topics of glider studies and their synergy with other observing platforms. Studies focused on technical details

17 of gliders were not included. Note that usage of a scientific database might cause slight bias or exclusion of some operational monitoring carried out for environmental or defence 
1 applications. There are only 36 scientific papers where glider data were exclusively used, 2 indicating that in most cases glider data are used in conjunction with other types of 3 measurement platforms.

4 Overall, a combination of glider data with data from research ships was the most common 5 combination (65 papers). This is possibly because data collected from the research vessels complemented glider data by several means: adding data that are not acquirable with a glider (e.g. currents profiling); collecting high quality data to calibrate glider sensor data; extending temporal (including historical data) and spatial coverage of data.

Glider-gathered data are often (62 papers) combined with remotely-sensed data products. Remote sensing can provide a high-resolution quasi synoptic view of the surface layer, while gliders complement that information by vertical (in-situ) structure of the water column (e.g. Bouffard et al. 2010; Alvarez et al. 2013). In 40 papers gliders were used in combination with data from moorings, including coastal stations. Gliders and moorings supplement each other, as moorings are capable of collecting high-resolution temporal data over longer period while gliders can obtain a spatial picture around mooring location. Often it is difficult to identify if a local (mooring) change is related to propagating anomalies (e.g. fronts, eddies) or to local processes (e.g. vertical mixing). In coastal regions gliders have been used in synergy with HF radars (15 papers), which can provide comprehensive spatial maps of surface waves- and current patterns, but do not gather vertical structure of the water column (e.g. Weingartner et al. 2013). Argo (16 papers), surface drifters (5 papers) and XBT lines (6 papers) have been used in combination with glider data. In these cases, the gliders navigational capabilities allow the collection of data in targeted areas, such are boundary currents (Davis et al. 2012) or other variable areas/processes (Frajka-Williams et al. 2009), where present GOOS systems are only available at selected locations or times.

In respect to disciplines, the most popular research area of glider-studies was physical oceanography: 126 papers are directly (primary subject in 51 papers) or indirectly (secondary subject in 75 papers) addressing investigations on hydrography. A popular topic (87 papers) was circulation and current structure. There are several papers in which gliders have 
organisms in very different trophic levels (phyto- and zooplankton, fishes, marine mammals) have been investigated using gliders as the observing platform. Fish and marine mammal mapping studies have been carried out using acoustic measurements. There are not many noise/acoustic studies published yet (9 papers), but sound and anthropogenic noise in water and its consequences to the ecosystem, are generally understudied so far in the world ocean. In that respect acoustics in water might be another future niche for gliders (e.g. Klinck et al. 2012; Baumgartner and Fratantoni 2008). The further development of acoustic measurements on-board gliders may lead to increased use of gliders in geological oceanography and sedimentology (7 papers) as well.

Process studies with gliders often address mesoscale or sub-mesoscale processes (81 papers). The ability to acquire information at that scale is an important strength of gliders. Profiles a few kilometres apart can identify for example the processes of cross-frontal exchange and eddy overturning (e.g. Heywood et al. 2014; Thompson et al. 2014).

Motions at different scales like tides, internal waves and turbulence have been studied by using gliders (20 papers). Direct measurements of ocean turbulence (e.g. Beaird et al. 2012, Fer et al. 2014) have shown that a glider offers a low noise platform suitable for ocean microstructure measurements.

There are two main roles of gliders in climatological studies ( 7 papers): extension or complementing (e.g. Albretsen et al. 2012) of long time-series with glider data and using glider data to interpret historical time-series (e.g. Karstensen et al. 2014).

The exploitation of gliders in marginal seas or coastal areas has become common (78 papers). Some studies use glider data in the context of coastal observing systems to validate/assimilate operational models. Gliders are well established in a number of coastal observatories, such as COSYNA (Stanev et al. 2011), SOCIB (Tintoré et al. 2013), Cyprus (Hayes et al, 2011; 2014), IOOS (Willis 2013), US OOI (Schofield et al. 2010) and IMOS (Hill et al. 2010).

Model performance studies have shown (21 papers) that assimilation of the glider-collected high-resolution data into models improves the ability of simulations. For instance Dobricic et al. (2010) have documented positive impact of glider data assimilation on temperature, salinity and flow fields. They even found that positive impact of glider observation remains several months after the presence of a glider. Moreover the transition of ocean forecast models and reanalysis systems towards higher resolution (e.g. $1 / 12^{\circ}$ degree is used at many 
1 centres already) requires matching high resolution in-situ sampling. While satellite and 2 underway systems can provide very high resolution sampling at the sea surface, gliders might 3 be the only autonomously operated in-situ platform that can resolve the vertical dimension at 4 the necessary lateral scale.

530 published papers demonstrate that gliders can operate in high latitudes and even under ice 6 (Beszczynska-Möller et al. 2011) to some extent. Gliders have been used quite often (45 7 papers) also in ocean boundary current regions (e.g. Todd et al. 2011, Davis et al. 2012, 8 Hoydalsvik et al. 2013). 
Table A1: Selected publications, where glider data is included in analysis. Topics were distinguished by importance of given study and 2 marked as primary (P) or secondary (S). If there was another measurement platform used in a study beside glider, it is marked by x".

\begin{tabular}{|c|c|c|c|c|c|c|c|c|c|c|c|c|c|c|c|c|c|c|c|c|}
\hline Publication & 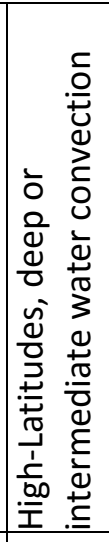 & 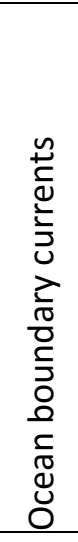 & 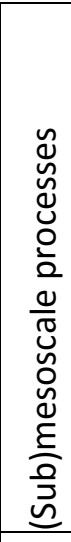 & 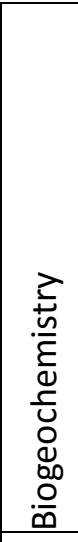 & $\begin{array}{l}\text { वे } \\
\text { 음 } \\
\frac{0}{9}\end{array}$ & 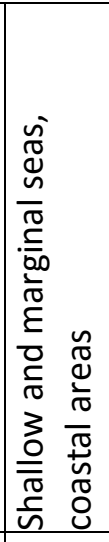 & 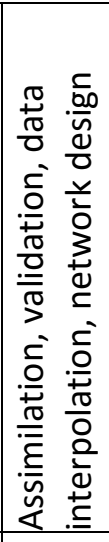 & 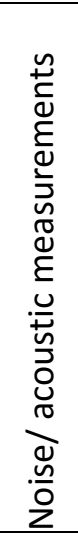 & 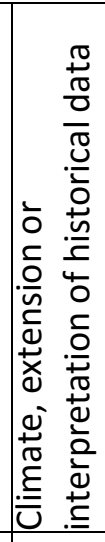 & 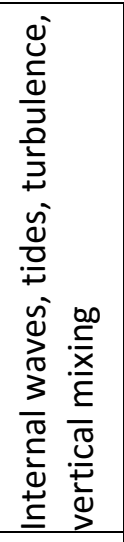 & 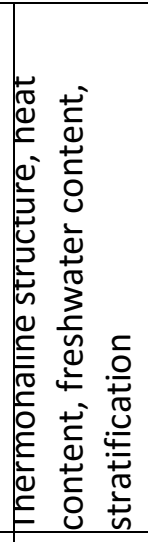 & 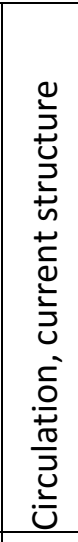 & 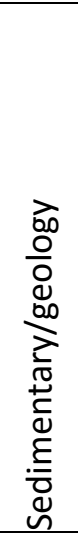 & 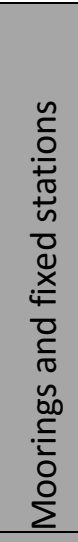 & 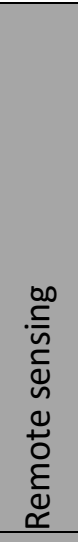 & 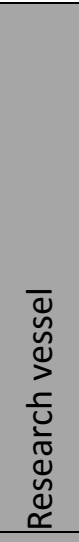 & 品 & $\begin{array}{l} \\
\\
\\
\frac{n}{\pi} \\
\frac{\pi}{0} \\
\frac{\pi}{2} \\
\frac{U}{I} \\
\end{array}$ & 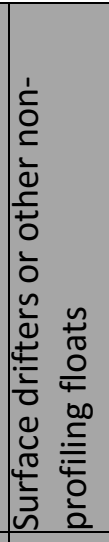 & $\begin{array}{l}\stackrel{-}{x} \\
\stackrel{x}{\leq}\end{array}$ \\
\hline All & 30 & 45 & 81 & 39 & 39 & 78 & 21 & 9 & 7 & 20 & 126 & 85 & 7 & 40 & 62 & 65 & 16 & 15 & 5 & 6 \\
\hline Primary subject & 12 & 10 & 30 & 15 & 27 & 23 & 19 & 7 & 5 & 14 & 51 & 28 & 6 & & & & & & & \\
\hline Secondary subject & 18 & 35 & 51 & 24 & 12 & 55 & 2 & 2 & 2 & 6 & 75 & 57 & 1 & & & & & & & \\
\hline Ainley et al. 2015 & $\mathrm{~S}$ & & & & $P$ & & & & & & & & & & & $\mathrm{x}$ & & & & \\
\hline Albretsen et al. 2012 & $\mathrm{~s}$ & $\mathrm{~s}$ & & & & $\mathrm{P}$ & & & $\mathrm{P}$ & & $\mathrm{P}$ & $S$ & & $x$ & & $x$ & & & & \\
\hline Alford et al. 2012 & & $\mathrm{~s}$ & $\mathrm{~s}$ & $\mathrm{~s}$ & $\mathrm{~S}$ & & & & & $\mathrm{P}$ & $\mathrm{S}$ & $\mathrm{S}$ & & $x$ & & & & & & \\
\hline Alvarez \& Mourre 2012 & & & & & & $\mathrm{~s}$ & $P$ & & & & $\mathrm{~s}$ & & & & $\mathrm{x}$ & $\mathrm{x}$ & & & & \\
\hline Alvarez et al. 2013 & & & $S$ & & & $\mathrm{~S}$ & $\mathrm{~S}$ & & & & $\mathrm{P}$ & $P$ & & & $x$ & $x$ & & & & \\
\hline Asper et al. 2011 & $\mathrm{P}$ & & & $\mathrm{S}$ & $\mathrm{P}$ & & & & & & $\mathrm{S}$ & & & & & & & & & \\
\hline Baird \& Ridgway 2012 & & $\mathrm{~s}$ & $\mathrm{P}$ & $\mathrm{S}$ & & & & & $\mathrm{P}$ & & $\mathrm{S}$ & $\mathrm{S}$ & & $\mathrm{x}$ & $\mathrm{x}$ & $\mathrm{x}$ & $x$ & & & \\
\hline Baird et al. 2011 & & $\mathrm{~s}$ & $P$ & $P$ & $\mathrm{~s}$ & & & & & & $\mathrm{~S}$ & $\mathrm{~S}$ & & $x$ & $x$ & $x$ & $x$ & & & \\
\hline $\begin{array}{l}\text { Baumgartner \& Fratantoni } \\
2008\end{array}$ & & & & & $\mathrm{P}$ & & & $\mathrm{P}$ & & & $\mathrm{s}$ & & & & & $x$ & & & & \\
\hline Baumgartner et al. 2008 & & & & & $\mathrm{P}$ & & & $\mathrm{P}$ & & & $\mathrm{S}$ & & & & & $x$ & & & & \\
\hline Beaird et al. 2012 & $\mathrm{P}$ & & $\mathrm{s}$ & & & & & & & $\mathrm{P}$ & $\mathrm{S}$ & $\mathrm{s}$ & & & & $x$ & & & & \\
\hline Beaird et al. 2013 & $\mathrm{~s}$ & $\mathrm{~s}$ & & & & & & & & & $P$ & $P$ & & & & & & & $\mathrm{x}$ & \\
\hline
\end{tabular}




\begin{tabular}{|c|c|c|c|c|c|c|c|c|c|c|c|c|c|c|c|c|c|}
\hline $\begin{array}{l}\text { Beszczynska-Möller et al. } \\
2011\end{array}$ & $\mathrm{P}$ & $S$ & $S$ & & & & & & $\mathrm{P}$ & $S$ & & $x$ & & & & & \\
\hline Biddle et al. 2015 & $S$ & & & $P$ & $P$ & & & & $\mathrm{~S}$ & & & & $\mathrm{x}$ & & & & \\
\hline Boettger et al. 2015 & & & $S$ & & & $S$ & & $\mathrm{P}$ & $\mathrm{S}$ & & & & & & & & \\
\hline Bosse et al. 2015 & & & $\mathrm{P}$ & & & $\mathrm{S}$ & & & $\mathrm{P}$ & $\mathrm{S}$ & & & $x$ & $x$ & $x$ & & \\
\hline Bouffard et al. 2010 & & & $\mathrm{P}$ & & & $\mathrm{P}$ & & & $\mathrm{S}$ & $S$ & & & $x$ & & & & \\
\hline Bouffard et al. 2012 & & & $\mathrm{P}$ & & & $\mathrm{P}$ & & & $\mathrm{S}$ & $\mathrm{S}$ & & & $x$ & & & & \\
\hline Bourrin et al. 2015 & & & & $\mathrm{~S}$ & & $S$ & & & $S$ & & $\mathrm{P}$ & $x$ & $x$ & $x$ & & & \\
\hline Briggs et al. 2011 & $\mathrm{~S}$ & & & $S$ & $\mathrm{P}$ & & & & & & & & & $x$ & & & \\
\hline Brown et al. 2012 & & & & & & $S$ & & & $\mathrm{P}$ & & & & $x$ & $x$ & & $x$ & \\
\hline Castelao et al. 2008 & & & $\mathrm{~S}$ & & & $\mathrm{P}$ & & & $\mathrm{P}$ & & & & & & & & \\
\hline Castelao et al. 2010 & & & $\mathrm{~S}$ & & & $\mathrm{P}$ & & & $\mathrm{P}$ & & & & & & & & \\
\hline Chao et al. 2008 & & & & & & $\mathrm{P}$ & $\mathrm{P}$ & & $\mathrm{S}$ & $\mathrm{S}$ & & $x$ & $x$ & $x$ & & $x$ & \\
\hline Cole and Rudnick 2012 & & & $\mathrm{P}$ & & & & & & $\mathrm{P}$ & $\mathrm{S}$ & & & & & & & \\
\hline Couvelard et al. 2008 & & $S$ & $S$ & & & & $\mathrm{P}$ & & $\mathrm{S}$ & $\mathrm{P}$ & & & & & & & \\
\hline Cronin et al. 2015 & & & & & & & & $\mathrm{P}$ & $\mathrm{P}$ & & & $x$ & & $x$ & $x$ & & \\
\hline Davis 2010 & & & $S$ & & & $\mathrm{P}$ & & & $\mathrm{S}$ & $\mathrm{P}$ & & & & & & & \\
\hline Davis et al 2012 & & $\mathrm{P}$ & & & & & & & $\mathrm{S}$ & $\mathrm{P}$ & & & & & & & \\
\hline Davis et al. 2008 & & $\mathrm{P}$ & $S$ & & $S$ & $\mathrm{~S}$ & & & $\mathrm{P}$ & $\mathrm{S}$ & & & & & & & \\
\hline de Madron 2012 & & & $S$ & & & $\mathrm{P}$ & & & $\mathrm{P}$ & $S$ & & $x$ & $x$ & $x$ & & & \\
\hline Dobricic et al. 2010 & & & $S$ & & & $\mathrm{P}$ & $P$ & & $\mathrm{~S}$ & $S$ & & & & & & & \\
\hline Domingues et al. 2015 & & & & & & & & $S$ & $\mathrm{P}$ & & & & $x$ & $x$ & & & \\
\hline Evans et al. 2013 & $\mathrm{P}$ & & $\mathrm{S}$ & $\mathrm{P}$ & & & & & $\mathrm{S}$ & & & & & $x$ & & & \\
\hline Evans et al. 2013b & $S$ & & $\mathrm{~S}$ & $P$ & & $\mathrm{~S}$ & & & $\mathrm{~S}$ & & & & & $x$ & & & \\
\hline Fan et al. 2013 & $\mathrm{P}$ & $S$ & $\mathrm{P}$ & & & & & & $S$ & $S$ & & $x$ & $x$ & $x$ & $x$ & & $x$ \\
\hline Farrar et al. 2015 & & & & & & & & & $\mathrm{P}$ & $S$ & & $x$ & $x$ & & $x$ & & \\
\hline Fer et al. 2014 & & & & & & & & $\mathrm{P}$ & $\mathrm{S}$ & & & & & $x$ & & & \\
\hline Frajka-Williams et al. 2009 & $S$ & $\mathrm{~S}$ & $\mathrm{P}$ & $\mathrm{S}$ & $\mathrm{P}$ & & & & $\mathrm{P}$ & $\mathrm{S}$ & & & $x$ & & & & \\
\hline Frajka-Williams et al. 2011 & $\mathrm{~s}$ & & & & & & & & & $\mathrm{P}$ & & & & & & & \\
\hline
\end{tabular}




\begin{tabular}{|c|c|c|c|c|c|c|c|c|c|c|c|c|c|c|c|c|c|c|c|c|}
\hline Gangopadhyay et al. 2013 & & & $\mathrm{P}$ & & & $\mathrm{S}$ & $P$ & & & & $\mathrm{~S}$ & $\mathrm{~S}$ & & & $x$ & & & $\mathrm{x}$ & & \\
\hline Glenn et al. 2008 & & & & $\mathrm{~S}$ & & $\mathrm{P}$ & & & & $\mathrm{S}$ & $\mathrm{S}$ & $S$ & $\mathrm{P}$ & $x$ & & & & $x$ & & \\
\hline Gourdeau et al. 2008 & & $\mathrm{P}$ & $S$ & & & & & & & & $\mathrm{~S}$ & $P$ & & & & $x$ & $x$ & & & \\
\hline Gower et al. 2013 & & & & $S$ & $\mathrm{P}$ & $\mathrm{P}$ & & & & & & & & $x$ & $x$ & $x$ & & & & \\
\hline Guihen et al. 2014 & $\mathrm{~S}$ & & & & $\mathrm{P}$ & & & $\mathrm{P}$ & & & & & & & & $x$ & & & & \\
\hline Haley Jr et al 2009 & & $\mathrm{~S}$ & $\mathrm{~S}$ & & & $\mathrm{~S}$ & $\mathrm{P}$ & & & & $S$ & $S$ & & & $x$ & $x$ & & $x$ & & \\
\hline Hátún et al. 2007 & $P$ & $S$ & $\mathrm{P}$ & & & & & & & & $P$ & $S$ & & & $x$ & & $x$ & & & \\
\hline Heslop et al. 2012 & & & $\mathrm{~S}$ & & & $\mathrm{~S}$ & & & & & $\mathrm{~S}$ & $\mathrm{P}$ & & $x$ & $x$ & $x$ & & & & \\
\hline Heywood et al. 2014 & $P$ & & $S$ & $\mathrm{~S}$ & & & & & & $\mathrm{~S}$ & $P$ & $S$ & & & & $x$ & & & & \\
\hline Hodges and Fratantoni 2009 & & $\mathrm{~S}$ & $\mathrm{P}$ & & $\mathrm{P}$ & & & & & $S$ & $\mathrm{~S}$ & $S$ & & & $x$ & & & & & \\
\hline Houpert et al. 2015 & & & & & & $\mathrm{~S}$ & & & $\mathrm{P}$ & & $\mathrm{P}$ & & & & & $x$ & $x$ & & & $x$ \\
\hline Hoydalsvik et al. 2013 & $P$ & $S$ & & & & & & & $\mathrm{~S}$ & & $\mathrm{P}$ & $\mathrm{P}$ & & $x$ & $x$ & $x$ & & & & \\
\hline Hristova et al. 2014 & & $\mathrm{~S}$ & $\mathrm{P}$ & & & & & & & & $S$ & $S$ & & & $x$ & & & & & \\
\hline Jacox et al. 2015 & & & & $\mathrm{P}$ & $\mathrm{P}$ & & $\mathrm{P}$ & & & & & & & & $x$ & $x$ & & & & \\
\hline Johnston \& Rudnick 2015 & & & & & & $\mathrm{~S}$ & & & & $\mathrm{P}$ & $S$ & $S$ & & & & & & & & \\
\hline Johnston et al. 2013 & & $\mathrm{~S}$ & & & & & & & & $\mathrm{P}$ & $\mathrm{S}$ & $\mathrm{P}$ & & $x$ & & & & & & \\
\hline Johnston et al. 2015 & & & & & & & & & & $\mathrm{P}$ & $\mathrm{S}$ & & $S$ & & & & & & & \\
\hline Jones et al. 2012 & & $S$ & & & & $\mathrm{P}$ & $\mathrm{P}$ & & & & $S$ & & & $x$ & $x$ & & & & & \\
\hline Juza et al. 2013 & & & $\mathrm{~S}$ & & & $\mathrm{~S}$ & & & & & $\mathrm{P}$ & $\mathrm{P}$ & & & & $x$ & $x$ & & & $x$ \\
\hline Kahl et al. 2010 & $\mathrm{~S}$ & & & $\mathrm{~S}$ & $\mathrm{P}$ & $\mathrm{S}$ & & & & & $\mathrm{S}$ & & & & & & & & & \\
\hline Karstensen et al. 2014 & & & $\mathrm{P}$ & & & $\mathrm{P}$ & & $S$ & & & $S$ & & & $x$ & $x$ & $x$ & & & & \\
\hline Kaufman et al. 2014 & $S$ & & & $P$ & $\mathrm{~S}$ & $\mathrm{~S}$ & & & & & $S$ & & & & $x$ & $x$ & & & & \\
\hline Kessler et al. 2013 & & $S$ & $\mathrm{~S}$ & & & & & & $\mathrm{~S}$ & & $\mathrm{~S}$ & $\mathrm{P}$ & & & $x$ & & $x$ & & & $x$ \\
\hline Klinck et al. 2012 & & & & & $\mathrm{P}$ & $\mathrm{S}$ & & $\mathrm{P}$ & & & & & & & & & & & & \\
\hline Kohut et al. 2013 & $\mathrm{P}$ & & & $S$ & $\mathrm{~S}$ & $\mathrm{~S}$ & & & & & $\mathrm{P}$ & $\mathrm{P}$ & & $x$ & & $x$ & & & & \\
\hline L'Heveder et al. 2013 & & & $\mathrm{P}$ & & & & & $\mathrm{P}$ & & & $\mathrm{S}$ & & & & & & & & & \\
\hline Li et al. 2013 & $\mathrm{~S}$ & & $S$ & & & $\mathrm{P}$ & $\mathrm{P}$ & & & & $\mathrm{S}$ & $S$ & & $x$ & & $x$ & & $x$ & & \\
\hline Many et al. 2016 & & & & $\mathrm{~S}$ & & $\mathrm{P}$ & & & & & $\mathrm{P}$ & & $\mathrm{P}$ & $x$ & $x$ & $x$ & & & & \\
\hline Martin et al. 2009 & $S$ & & $\mathrm{P}$ & & & & & & & & $\mathrm{S}$ & $\mathrm{P}$ & & & $x$ & & & & $x$ & \\
\hline
\end{tabular}




\begin{tabular}{|c|c|c|c|c|c|c|c|c|c|c|c|c|c|c|c|c|c|c|c|}
\hline Mazzini et al. 2014 & $\mathrm{P}$ & $S$ & & & $\mathrm{P}$ & & & & & $\mathrm{P}$ & $\mathrm{P}$ & & $x$ & $x$ & & & & & \\
\hline Matsumoto et al. 2011 & & & & & & & $\mathrm{P}$ & & & & & $P$ & & & & & & & \\
\hline McClatchie et al. 2012 & $\mathrm{~S}$ & $S$ & & $\mathrm{P}$ & & & & & & $\mathrm{S}$ & $S$ & & & $x$ & $x$ & & & & \\
\hline Melet et al. 2012 & $\mathrm{~S}$ & & & & & $\mathrm{P}$ & & & & $\mathrm{S}$ & $\mathrm{S}$ & & & & & & & & \\
\hline Merckelbach et al. 2010 & & & & & & & & & & & $P$ & & & & & & & & \\
\hline Miles et al. 2013 & & & & & $\mathrm{P}$ & & & & $S$ & $S$ & $\mathrm{~S}$ & $\mathrm{P}$ & $x$ & & & & $x$ & & \\
\hline Miles et al. 2015 & & & & & $\mathrm{P}$ & & & & & $\mathrm{S}$ & $\mathrm{S}$ & $\mathrm{P}$ & & $x$ & & & & & \\
\hline Monteiro et al. 2015 & & & $P$ & & & & & & & & & & & $x$ & $x$ & & & & \\
\hline Mourre and Alvarez 2012 & & $S$ & & & $\mathrm{~S}$ & $\mathrm{P}$ & & & & $\mathrm{S}$ & & & $x$ & $x$ & $x$ & & & & \\
\hline Mourre et al. 2014 & & & & & $\mathrm{~S}$ & $\mathrm{P}$ & & & & $\mathrm{P}$ & & & & $x$ & & & & & \\
\hline Ngodock et al. 2014 & & $S$ & & & $\mathrm{~S}$ & $P$ & & & & $S$ & & & $x$ & & $x$ & & & & $x$ \\
\hline Nicholson et al. 2008 & & $\mathrm{~S}$ & $\mathrm{P}$ & $S$ & & & & & & $\mathrm{P}$ & & & $x$ & $x$ & & & & & \\
\hline Nicholson et al. 2015 & & & $\mathrm{P}$ & $\mathrm{P}$ & & & & & & $\mathrm{S}$ & & & $x$ & & & & & & \\
\hline Niewiadomska et al. 2008 & & $\mathrm{P}$ & $P$ & & $S$ & & & & & $\mathrm{~S}$ & $S$ & & & $x$ & $x$ & & & & \\
\hline Ohman et al. 2013 & $S$ & $S$ & $S$ & $S$ & $\mathrm{~S}$ & & & & & $S$ & $\mathrm{~S}$ & & $x$ & $x$ & $x$ & & & & \\
\hline Oke et al. 2009 & $\mathrm{~S}$ & & & & & $P$ & & & & $\mathrm{~S}$ & $\mathrm{~S}$ & & & & & & $x$ & & \\
\hline Olita et al. 2014 & & $S$ & & $\mathrm{P}$ & $\mathrm{S}$ & & & & & $\mathrm{P}$ & & & & $x$ & & & & & \\
\hline Oliver et al. 2013 & & $\mathrm{P}$ & $S$ & $\mathrm{P}$ & $\mathrm{S}$ & & & & & $S$ & $S$ & & & & & & & & \\
\hline Omand et al. 2015 & & $P$ & $\mathrm{P}$ & $S$ & & & & & & $S$ & & & & & & & & & \\
\hline Palmer et al. 2015 & & & & & & & & & $\mathrm{P}$ & $P$ & & & & & & & & & \\
\hline Pan et al. 2014 & & & & & $S$ & $\mathrm{P}$ & & & & & & & $x$ & & & & & & \\
\hline Pascual et al. 2010 & & $P$ & & & $\mathrm{~S}$ & & & & & $S$ & $S$ & & & $x$ & $x$ & & & $x$ & \\
\hline Pattiaratchi et al. 2010 & $\mathrm{~S}$ & $\mathrm{~S}$ & & $\mathrm{~S}$ & $\mathrm{~S}$ & & & & & $\mathrm{P}$ & $\mathrm{S}$ & & & & & & & & \\
\hline Pattiaratchi et al. 2011 & $\mathrm{~S}$ & $\mathrm{~S}$ & & & $P$ & & & & & $\mathrm{P}$ & $\mathrm{S}$ & & & & & & & & \\
\hline Pelland et al. 2013 & $S$ & $\mathrm{P}$ & & & $\mathrm{S}$ & & & & & $\mathrm{P}$ & $\mathrm{S}$ & & & & & & & & \\
\hline Pelland et al. 2014 & & $\mathrm{~S}$ & & $\mathrm{P}$ & $\mathrm{S}$ & & & & & $\mathrm{S}$ & $\mathrm{S}$ & & & $x$ & & $x$ & & & \\
\hline Perry et al. 2008 & & $\mathrm{~S}$ & $\mathrm{~S}$ & $\mathrm{P}$ & $\mathrm{S}$ & & & & & $\mathrm{P}$ & & & & $x$ & & & & & \\
\hline Pierce et al. 2012 & $\mathrm{~S}$ & & $\mathrm{P}$ & & $\mathrm{S}$ & & & $\mathrm{P}$ & & $\mathrm{S}$ & & & & & $x$ & & & & \\
\hline Pietri et al. 2013 & $\mathrm{~S}$ & $\mathrm{P}$ & $\mathrm{S}$ & & $\mathrm{S}$ & & & & & $P$ & $S$ & & & $x$ & $x$ & & & & \\
\hline
\end{tabular}




\begin{tabular}{|c|c|c|c|c|c|c|c|c|c|c|c|c|c|c|c|c|c|c|c|}
\hline Powell \& Ohman 2012 & & & & & $\mathrm{P}$ & & & $\mathrm{S}$ & & & & & & & $x$ & & & & \\
\hline Powell \& Ohman 2015 & & & $\mathrm{~S}$ & $\mathrm{~S}$ & $\mathrm{P}$ & $\mathrm{S}$ & & & & & $\mathrm{S}$ & $\mathrm{S}$ & & & & & & & \\
\hline Qiu et al. 2015 & & & & & & & & & & $\mathrm{~S}$ & $\mathrm{P}$ & & & $x$ & & & & & \\
\hline Queste et al. 2015 & $\mathrm{~S}$ & & & $P$ & $\mathrm{~S}$ & & & & & & $\mathrm{~S}$ & & & $x$ & $x$ & & & & \\
\hline Rainville et al. 2013 & & $\mathrm{~S}$ & $\mathrm{~S}$ & & & $\mathrm{~S}$ & & & & $\mathrm{P}$ & & & & & & & & & \\
\hline Ramp et al. 2009 & & $S$ & $\mathrm{P}$ & & & $\mathrm{S}$ & $\mathrm{P}$ & & & & $S$ & $\mathrm{P}$ & & $x$ & $x$ & & $x$ & & \\
\hline Ramp et al. 2011 & & $\mathrm{~S}$ & $\mathrm{~S}$ & & & $\mathrm{~S}$ & $\mathrm{~S}$ & & & & $\mathrm{~S}$ & $\mathrm{P}$ & $x$ & $x$ & & & & & \\
\hline Rayburn et al. 2013 & & & $\mathrm{~S}$ & & & $\mathrm{~S}$ & & & & & $\mathrm{P}$ & & & & $\mathrm{x}$ & $x$ & & & $x$ \\
\hline Rudnick and Cole 2011 & & & $\mathrm{~S}$ & & & & & & & $\mathrm{P}$ & $\mathrm{P}$ & & & & $x$ & & & & \\
\hline Rudnick et al. 2013 & & & & & & & & & & $\mathrm{P}$ & $\mathrm{S}$ & $S$ & & & & & & & \\
\hline Rudnick et al. 2015 & & & $\mathrm{P}$ & & & $S$ & & & & & $\mathrm{~S}$ & $\mathrm{~S}$ & & $x$ & & & & & \\
\hline Ruiz et al. 2009a & & & $\mathrm{P}$ & & & $\mathrm{S}$ & & & & & $\mathrm{P}$ & $S$ & & $x$ & $x$ & & & & \\
\hline Ruiz et al. 2009b & & & $\mathrm{S}$ & & & $\mathrm{S}$ & & & & & $\mathrm{P}$ & $\mathrm{P}$ & & $x$ & & & & & \\
\hline Ruiz et al. 2012 & & & $\mathrm{~S}$ & & & $\mathrm{~S}$ & & & & $\mathrm{P}$ & $\mathrm{P}$ & $\mathrm{S}$ & $x$ & & & & & & \\
\hline Schaeffer and Roughan 2015 & & $\mathrm{P}$ & $\mathrm{P}$ & & & $\mathrm{S}$ & & & & & $\mathrm{P}$ & & & & & & & & \\
\hline Schaeffer et al. 2014 & & $\mathrm{P}$ & $S$ & $\mathrm{~S}$ & $\mathrm{~S}$ & $\mathrm{~S}$ & & & & & $S$ & $\mathrm{P}$ & $x$ & $x$ & & & $x$ & & \\
\hline Schlundt et al. 2014 & & & & & & & & & & & $\mathrm{P}$ & $\mathrm{S}$ & $x$ & $x$ & $x$ & $x$ & & $x$ & \\
\hline Schöneau \& Rudnick 2015 & & & $\mathrm{~S}$ & & & & & & & & $S$ & $\mathrm{P}$ & & & & $x$ & & & \\
\hline Schöneau et al. 2015 & & $\mathrm{P}$ & & & & & & & & & $S$ & $\mathrm{P}$ & & & $x$ & $x$ & & & $x$ \\
\hline Seegers et al. 2015 & & & & $\mathrm{P}$ & $\mathrm{P}$ & $\mathrm{P}$ & & & & & & & $x$ & $x$ & $x$ & & & & \\
\hline Sherwin et al. 2012 & & $\mathrm{~S}$ & & $S$ & & & & & $\mathrm{P}$ & & $\mathrm{P}$ & & & & $x$ & & & & \\
\hline Sherwin et al. 2015 & & $S$ & $\mathrm{P}$ & & & & & & & & $S$ & $\mathrm{P}$ & & $x$ & $x$ & & & & \\
\hline Shulman et al. 2009 & & $\mathrm{~S}$ & & & & $\mathrm{P}$ & $\mathrm{P}$ & & & & $\mathrm{S}$ & $\mathrm{S}$ & $x$ & $x$ & & & & & \\
\hline Shulman et al. 2010 & & $\mathrm{~S}$ & $\mathrm{P}$ & & & $\mathrm{P}$ & & & & & $\mathrm{S}$ & $P$ & $x$ & & $x$ & & $x$ & & \\
\hline Swart et al. 2015 & $\mathrm{~S}$ & & $S$ & & $\mathrm{P}$ & & & & & & $\mathrm{P}$ & & & $x$ & $x$ & & & & \\
\hline Zhang et al. 2010 & & & & & & $\mathrm{P}$ & $\mathrm{P}$ & & & & $\mathrm{S}$ & $\mathrm{S}$ & & & & & & & \\
\hline Zhao et al. 2013 & & & $\mathrm{~S}$ & $\mathrm{~S}$ & $\mathrm{P}$ & $S$ & & & & & $\mathrm{~S}$ & $S$ & & $x$ & $x$ & & & & \\
\hline Thomalla et al. 2015 & $\mathrm{~S}$ & & $S$ & $\mathrm{~S}$ & $\mathrm{P}$ & & & & & & $S$ & & & & $x$ & & & & \\
\hline Thompson et al. 2014 & $\mathrm{P}$ & & $\mathrm{P}$ & & & & & & & & $\mathrm{P}$ & $S$ & & & & & & & \\
\hline
\end{tabular}




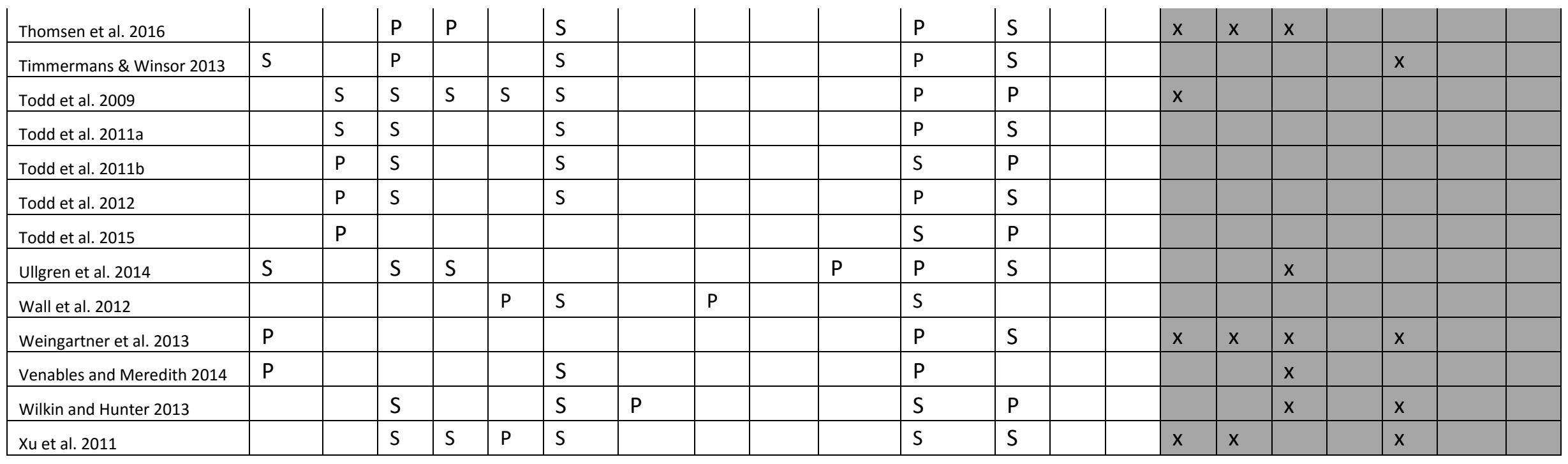


2

\section{References of the appendix:}

Ainley DG, Ballard G, Jones RM, Jongsomjit D, Pierce SD et al. Trophic cascades in the western Ross Sea, Antarctica: revisited. Mar Ecol Prog Ser. 2015; 534: 1-16.

Albretsen J, Aure J, Sætre R, Danielssen DS. 2012. Climatic variability in the Skagerrak and coastal waters of Norway. ICES Journal of Marine Science, 69, 758-763.

Alford MH, Mickett JB, Zhang S, MacCready P, Zhao ZX, Newton J. 2012. Internal waves on the Washington continental shelf. Oceanography, 25 (2), 66-79.

Alvarez A, Chiggiato J, Schroeder K. 2013. Mapping sub-surface geostrophic currents from altimetry and a fleet of gliders, Deep Sea Res.I, doi:10.1016/j.dsr.2012.10.014.

Alvarez A, Mourre B. 2012. Oceanographic field estimates from remote sensing and glider fleets, J. Atmos. Oceanic Technol., 29, 1657-1662. doi:10.1175/JTECH-D-12-00015.1

Asper V, Smith W, Lee C, Gobat J, Heywood K, Queste B, Dinniman M. 2011.Using gliders to study a phytoplankton bloom in the Ross Sea, Antarctica, OCEANS 2011, pp.1-7, 19-22 Sept. 2011.

Baird ME, Ridgway KR. 2012. The southward transport of sub-mesoscale lenses of Bass Strait Water in the centre of anti-cyclonic mesoscale eddies, Geophys. Res. Lett., 39, L02603, doi:10.1029/2011GL050643.

Baird ME, Suthers, IM, Griffin, DA, Hollings B, Pattiaratchi C, Everett, JD, Roughan M, Oubelkheir K, Doblin M. 2011.The effect of surface flooding on the physicalbiogeochemical dynamics of a warm-core eddy off southeast Australia. Deep Sea Res., $58(5), 592-605$.

Queste BY, Heywood KJ, Smith WO, Kaufman DE, Jickells TD, Dinniman MS. 2015.

Dissolved oxygen dynamics during a phytoplankton bloom in the Ross Sea polynya. Antarctic Science, 27, pp 362-372. doi:10.1017/S0954102014000881.

Baumgartner M, Fratantoni D. 2008. Diel periodicity in both sei whale vocalization rates and the vertical migration of their copepod prey observed from ocean gliders, Limnol. Oceanogr., 53(5, part 2), 2008, 2151.

Baumgartner MF, Van Parijs SM, Wenzel FW, Tremblay CJ, Esch HC, Warde AM. 2008. Low frequency vocalizations attributed to sei whales (Balaenoptera borealis). The Journal of the Acoustical Society of America 124, 1339-1349. 
Beaird N, Fer I, Rhines P, Eriksen C. 2012. Dissipation of Turbulent Kinetic Energy Inferred from Seagliders: An Application to the Eastern Nordic Seas Overflows, J. Phys. Oceanogr., 42, 2268-2282.

Beaird NL, Rhines PB, Eriksen C. 2013. Overflow Waters at the Iceland-Faroe Ridge Observed in Multiyear Seaglider Surveys. J. Phys. Oceanogr., 43, 2334-2351.

Beszczynska-Möller A, Woodgate RA, Lee C, Melling H, Karcher M. 2011. A synthesis of exchanges through the main oceanic gateways to the Arctic Ocean. Oceanography 24(3):82-99, http://dx.doi.org/10.5670/oceanog.2011.59.

Biddle LC, Kaiser J, Heywood KJ, Thompson AF, Jenkins A. 2015. Ocean glider observations of iceberg-enhanced biological production in the northwestern Weddell Sea, Geophys. Res. Lett., 42, 459-465, doi:10.1002/2014GL062850.

Boettger D, Robertson R, Rainville L. 2015. Characterizing the semidiurnal internal tide off Tasmania using glider data, J. Geophys. Res. Oceans, 120, 3730-3746, doi:10.1002/2015JC010711.

Bosse A, Testor, P Mortier L, Prieur L, Taillandier V, d'Ortenzio F, and Coppola L. 2015. Spreading of Levantine intermediate waters by submesoscale coherent vortices in the northwestern Mediterranean Sea as observed with gliders, J. Geophys. Res. Oceans, 120, 1599-1622, doi:10.1002/2014JC010263.

Bouffard J, Pascual A, Ruiz S, Faugère Y, Tintoré J. 2010. Coastal and mesoscale dynamics characterization using altimetry and gliders: a case study in the Balearic Sea. Journal of Geophyscal Research, 115, C10029, doi:10.1029/2009JC006087.

Bouffard J, Renault L, Ruiz S, Pascual P, Dufau C, Tintoré J. 2012. Sub-surface small scale eddy dynamics from multi-sensor observations and modelling, Progress in oceanography, 106, 62-79.

Bourrin F, Many G, Durrieu de Madron X, Martín J, Puig P, Houpert L, Testor P, Kunesch S, Mahiouz K, Béguery L. 2015. Glider monitoring of shelf suspended particle dynamics and transport during storm and flooding conditions. Cont. Shelf Res. 109 (10), 135-149. http://dx.doi.org/10.1016/j.csr.2015.08.031

Briggs N, Perry MJ, Cetinic I, Lee CM, D'Asaro E, Gray A, Rehm E. 2011. High resolution observations of aggregate flux during a sub-polar North Atlantic spring bloom. DeepSea Res. I: Oceanogr. Res. Pap. 58 (10), 1031-1039. 
Brown W, Boicourt W, Flagg C, Gangopadhyay A, Schofield O, Glenn S, Kohut J. 2012. Mapping the Mid-Atlantic Cold Pool evolution and variability with ocean gliders and numerical models.Oceans, 2012, 14-19 Oct. 2012, doi:10.1109/OCEANS.2012.6404970.

Castelao R, Glenn S, Schofield O, Chant R, Wilkin J, Kohut J. 2008. Seasonal evolution of hydrographic fields in the central Middle Atlantic Bight from glider observations. Geophysical Research Letters doi:10.1029/2007GL032335.

Castelao R, Glenn S, Schofield O. 2010.Temperature, salinity, and density variability in the central Middle Atlantic Bight, J. Geophys. Res.,115, C10005, doi:10.1029/2009JC006082.

Chao Y, Li Z, Farrara JD, Moline MA, Schofield O, Majumdar SJ. 2008. Synergistic applications of autonomous underwater vehicles and regional oceanmodeling system in coastal ocean forecasting. Limnology and Oceanography, 53(6), 2251-2263.

Cole ST, Rudnick DL. 2012. The spatial distribution and annual cycle of upper ocean thermohaline structure. J. Geophys.Res., doi: 10.1029/2011JC007033.

Couvelard X, Marchesiello P, Gourdeau L, Lefèvre J. 2008. Barotropic Zonal Jets Induced by Islands in the Southwest Pacific, J. Phys. Oceanogr ., 38, 3, 2185-2204.

Cronin MF, Pelland NA, Emerson SR, and Crawford WR. 2015. Estimating diffusivity from the mixed layer heat and salt balances in the North Pacific, J. Geophys. Res. Oceans, 120, 7346-7362, doi:10.1002/2015JC011010.

Davis R, Ohman MD, Rudnick DL, Sherman J, Hodges B. 2008. Glider surveillance of physics and biology in the southern California Current System, Limnol.Oceanogr., 53(5, part 2), 2151-2168.

Davis RE, Kessler WS, Sherman JT. 2012. Gliders measure western boundary current transport from the South Pacific to the equator. J. of Phys. Oceanography, 42 (11), 2001-2013.

Davis RE. 2010. On the coastal-upwelling overturning cell.Journal of Marine Research, Volume 68, Numbers 3-4, May-July 2010, pp. 369-385(17)

de Madron XD, Houpert L, Puig P, Sanchez-Vidal A, Testor P, Bosse A, Estournel C, Somot S, Bourrin F, Bouinet MN, al, 2013. Interaction of dense shelf water cascading and open-sea convection in the northwestern Mediterranean during winter 2012, Geophys. Res. Lett., 40, doi:10.1002/grl.50331. 
Dobricic S, Pinardi N, Testor P, Send U. 2010. Impact of data assimilation of glider observations in the Ionian Sea (Eastern Mediterranean), Dynamics of Atmospheres and Oceans, Volume 50, Issue 1, 78-92, doi:10.1016/j.dynatmoce.2010.01.001.

Domingues R, Goni G, Bringas F, Lee S-K, Kim H-S, Halliwell G, Dong J, Morell J, Pomales L. 2015. Upper ocean response to Hurricane Gonzalo (2014): Salinity effects revealed by targeted and sustained underwater glider observations, Geophys. Res. Lett., 42, 7131-7138, doi:10.1002/2015GL065378.

Evans W, Strutton PG, Chavez FP. 2013. Impact of tropical instability waves on nutrient and chlorophyll distributions in the equatorial Pacific. Deep Sea Res. P1, Oceanographic Res. Papers, 56 (2), 178-188.

Evans W, Mathis JT, Winsor P, Statscewich H, Whitledge TE. 2013. A regression modeling approach for studying carbonate system variability in the northern Gulf of Alaska, J. Geophys. Res. Oceans, 118, 476-489, doi:10.1029/2012JC008246.

Fan X, Send U, Testor P, Karstensen J, L'herminier P. 2013. Observations of Irminger Sea Anticyclonic Eddies, J. Phys. Oceanogr., 43, 805-823. doi:10.1175/JPO-D-11-0155.1

Farrar JT, Rainville L, Plueddemann AJ, Kessler WS, Lee C, et al. 2015. Salinity and temperature balances at the SPURS central mooring during fall and winter. Oceanography 28(1):56-65

Fer I, Peterson AK, Ullgren JE. 2014. Microstructure Measurements from an Underwater Glider in the Turbulent Faroe Bank Channel Overflow. Journal of Atmospheric and Oceanic Technology, 31, 1128-1150.

Frajka-Williams E, Eriksen C, Rhines PB, Harcourt RR. 2011.Determining Vertical Water Velocities from Seaglider. J. Atmos\& Oceanic Tech., 28, 1641-1656. DOI:10.1175/2011JTECHO830.1

Frajka-Williams E, Rhines PB, Eriksen CC. 2009. Physical controls and mesoscale variability in the Labrador Sea spring phytoplankton bloom observed by Seaglider. Deep Sea Res., 56 (12), 2144-2161, DOI: 10.1016/j.dsr.2009.07.008.

Gangopadhyay A, Schmidt A, Agel L, Schofield O, Clark J. 2013. Multi-scale forecasting in the western north Atlantic: Sensitivity of model forecast skill to glider data assimilation.Cont. Shelf Res., 63, 159-176. 
Glenn S, Jones C, Twardowski M, Bowers L, Kerfoot J, Kohut J, Webb D, Schofield O. 2008. Glider observations of sediment resuspension in a Middle Atlantic Bight fall transition storm. Limnol.Oceanogr., 53(5, part 2), 2180-2196.

Gourdeau L, Kessler WS, Davis RE, Sherman J, Maes C, Kestenare E. 2008. Zonal jets entering the Coral Sea, J. Phys. Oceanogr ., 38, No. 3, 714-724.

Gower J, King S, Statham S, Fox R, Young E. 2013: The Malaspina Dragon: A newlydiscovered pattern of the early spring bloom in the Strait of Georgia, British Columbia, Canada, ProgOceanogr, 115, 181-188, doi:10.1016/j.pocean.2013.05.024

Guihen D, Fielding S, Murphy EJ, Heywood KJ, Griffiths G. 2014. An assessment of the use of ocean gliders to undertake acoustic measurements of zooplankton: the distribution and density of Antarctic krill (Euphausiasuperba) in the Weddell Sea. Limnology and Oceanography-Methods, 12, 373-389.

Haley Jr PJ, Lermusiaux PFJ, Robinson AR, Leslie WG, Logutov O, Cossarini G, Liang XS, Moreno P, Ramp SR, Doyle JD, et al. 2009. Forecasting and Reanalysis in the Monterey Bay/California Current Region for the Autonomous Ocean Sampling Network-II Experiment. Special issue on AOSN-II. Deep Sea Res. II, doi:10.1016/j.dsr2.2008.08.010.

Hátún H, Eriksen CC, Rhines PB. 2007. Buoyant eddies entering the Labrador Sea observed with gliders and altimetry. Journal of Physical Oceanography 37:2,838-2,854.

Hayes D, Hannides A, Testor P, Gildor H, Zodiatis G, Georgiou G. 2014. Description of the Long-lived Subsurface Mesoscale Eddy South of Cyprus.6 ${ }^{\text {th }}$ EGO Meeting 16-17 June, Kiel, Germany.

Hayes D, Zodiatis G, Konnaris G, Hannides A, Solovyov D, Testor P. 2011. Glider transects in the Levantine Sea: Characteristics of the warm core Cyprus eddy. Presented at the Oceans 2011 IEEE, IEEE, Santander, Spain, p. Paper PID1762407. doi:10.1109/Oceans-Spain.2011.6003393

Heslop EE, Ruiz S, Allen J, López-Jurado JL, Renault L, Tintoré J. 2012. Autonomous underwater gliders monitoring variability at choke points" in our ocean system: A case study in the Western Mediterranean Sea. Geophys. Res. Lett., 39, L20604, doi:10.1029/2012GL053717. 
Heywood KJ, Schmidtko S, Heuze C, Kaiser J, Jickells TD, Queste BY, Stevens DP, Wadley M, Thompson AF, Fielding S, et al. 2014. Ocean processes at the Antarctic continental slope, Phil Trans. Roy. Soc.A, 372, 20130047.

Hill K, Moltmann T, Proctor R, Allen S. 2010.The Australian integrated marine observing system: delivering data streams to address national and international research priorities. Mar. Technol. Soc. J., 44 (6), pp. 65-72

Hodges BA, Fratantoni DM, 2009. A thin layer of phytoplankton observed in the Philippine Sea with a synthetic moored array of autonomous gliders. Journal of Geophysical Research - Oceans, 114, doi:10.1029/2009JC005294.

Houpert L, Testor P, Durrieu de Madron X, Somot S, D’Ortenzio F, Estournel C, Lavigne H. 2014. Observations of the mixed layer, the seasonal thermocline and the upper-ocean heat storage rate to estimate the seasonal cycle of the net heat flux over the Mediterranean Sea. Prog Oceanogr. doi:10.1016/j.pocean.2014.11.004

Høydalsvik F, Mauritzen C, Orvik KA, LaCasce JH, Lee CM, J. Gobat J. 2013. Transport estimates of the Western Branch of the Norwegian Atlantic Current from glider surveys, Deep Sea Res. Part I, 79, 86-95, doi:10.1016/j.dsr.2013.05.005

Hristova HG, Kessler WS, McWilliams JC, Molemaker MJ. 2014. Mesoscale variability and its seasonality in the Solomon and Coral Seas. Journal of Geophysical ResearchOceans, 119, 4669-4687.

IOC. 1997. Global Sea Level Observing System (GLOSS) implementation plan -1997. Intergovernmental Oceanographic Commission, Technical Series, No. 50, 91pp. \& Annexes.

Jacox MG, Edwards CA, Kahru M, Rudnick DL, Kudela RM. 2015. The potential for improving remote primary productivity estimates through subsurface chlorophyll and irradiance measurement. Deep-Sea Res. II 112:107-16

Johnston TMS, Rudnick DL, Kelly SM. 2015. Standing Internal Tides in the Tasman Sea Observed by Gliders. Journal of Physical Oceanography, 45, 2715-2737, doi: 10.1175/JPO-D-15-0038.1.

Johnston TMS, Rudnick DL. 2015. Trapped diurnal internal tides, propagating semidiurnal internal tides, and mixing estimates in the California Current System from sustained glider observations, 2006-2012. Deep-Sea Res. II. 112, 61-78, http://dx.doi.org/10.1016/j.dsr2.2014.03.009 
Johnston, TMS, Rudnick DL, Alford MH, Pickering A, Simmons HL. 2013. Internal tidal energy fluxes in the South China Sea from density and velocity measurements by gliders. J. Geophys. Res. Oceans, 118, 3939-3949.

Jones EM, Oke PR, Rizwi F, Murray L. 2012. Assimilation of glider and mooring data into a coastal ocean model. Ocean Modell., 47,1-13, doi:10.1016/j.ocemod.2011.12.009.

Juza M, Renault L, Ruiz S, Tintoré J. 2013. Origin and pathways of Winter Intermediate Water in the Northwestern Mediterranean Sea using observations and numerical simulation. Journal of Geophysical Research-Oceans, 118, 6621-6633.

Kahl A, Fraser W, Schofield O. 2010. Autonomous gliders reveal water column features associated with Adélie penguin foraging. Integrative and Comparative Biology doi: 10.1093/icb/icq098

Karstensen J, Liblik T, Fischer J, Bumke K, Krahmann G. 2014. Summer upwelling at the Boknis Eck time-series station (1982 to 2012) - a combined glider and wind data analysis.Biogeosciences, 11, 3603-3617.

Kaufman D, Friedrichs MAM, Smith WO, Queste BY, Heywood KJ. 2014.

Biogeochemical variability in the southern Ross Sea as observed by a glider deployment. Deep-Sea Research I, 92, 93-106.

Kessler WS, Cravatte S. 2013. ENSO and Short-Term Variability of the South Equatorial Current Entering the Coral Sea. J. Phys. Oceanogr., 43, 956-969. doi: http://dx.doi.org/10.1175/JPO-D-12-0113.1

Klinck H, Mellinger DK, Klinck K, Bogue NM, Luby JC, et al. 2012. Near-Real-Time Acoustic Monitoring of Beaked Whales and Other Cetaceans Using a SeagliderTM.PLoS ONE 7(5): e36128. doi:10.1371/journal.pone.0036128

Kohut J, Hunter E, and Huber B. 2013. Small-scale variability of the cross-shelf flow over the outer shelf of the Ross Sea, J. Geophys. Res. Oceans, 118, 1863-1876, doi:10.1002/jgrc.20090.

L'Hévéder B, Mortier L, Testor P, Lekien F. 2013. A Glider Network Design Study for a Synoptic View of the Oceanic Mesoscale Variability. J. Atmos. Oceanic Technol., 30, 1472-1493. doi: http://dx.doi.org/10.1175/JTECH-D-12-00053.1 
Li Z, Chao Y, Farrara JD, McWilliams JC. 2013. Impacts of distinct observations during the 2009 Prince William Sound field experiment: a data assimilation study. Cont. Shelf Res. 63, 209-222.

Many G, Bourrin F, Durrieu de Madron X, Pairaud I, Gangloff A, Doxaran D, Ody A, Verney R, Menniti C, Le Berre D, Jacquet M. 2016. Particle assemblage characterization in the Rhone River ROFI, Journal of Marine Systems, Volume 157, May 2016, Pages 39-51, ISSN 0924-7963, http://dx.doi.org/10.1016/j.jmarsys.2015.12.010.

Martin JP, Lee CM, Eriksen CC, Ladd C, Kachel NB. 2009. Kinematics of a Gulf of Alaska Eddy as Observed with Seaglider, J. Geophys.Res., 114, C12021.

Matsumoto H, Haxel JH, Dziak RP, Bohnenstiehl DR, Embley RW. 2011. Mapping the sound field of an erupting submarine volcano using an acoustic glider. J. Acoust. Soc. Am., 129, 94-99.

McClatchie S, Cowen R, Nieto K, Greer A, Luo JY, Guigand C, Demer D, Griffith D, Rudnick D. 2012.Resolution of fine biological structure including small narcomedusae across a front in the Southern California Bight. J. Geophys. Res. 117, C04020, doi:10.1029/2011JC007565.

Melet A, Verron J, Brankart J-M. 2012. Potential outcomes of glider data assimilation in the Solomon Sea: control of the water mass properties and parameter estimation. Journal of Marine Systems, 94, 232-246, DOI: 10.1016/j.jmarsys.2011.12.003.

Merckelbach LM, Smeed DA, Griffiths G. 2010.Vertical water velocities from underwater gliders. J. Atmos\& Oceanic Tech. 3(27), 547-563. DOI:10.1175/2009JTECHO710.1

Miles T, Glenn SM, Schofield, O. 2013. Temporal and spatial variability in fall storm induced sediment resuspension on the Mid-Atlantic Bight. Coastal Ocean Observing System, 63, 36-49.

Miles T, Seroka G, Kohut J, Schofield O, Glenn S. 2015. Glider observations and modeling of sediment transport in Hurricane Sandy. J. Geophys. Res. Oceans 120:1771-91

Monteiro, PMS, Gregor L, Lévy M, Maenner S, Sabine C L, and Swart S. 2015. Intraseasonal variability linked to sampling alias in air-sea $\mathrm{CO} 2$ fluxes in the Southern Ocean, Geophys. Res. Lett., 42, 8507-8514, doi:10.1002/2015GL066009.

Mourre B, Alvarez A. 2012. Benefit assessment of glider adaptive sampling in the Ligurian Sea. Deep-Sea Res., 68, 68-78, doi:10.1016/j.dsr.2012.05.010. 
Mourre B, Chiggiato J. 2014. A comparison of the performance of the 3-D super-ensemble and an ensemble Kalman filter for short-range regional ocean prediction. Tellus Series a-Dynamic Meteorology and Oceanography, 66.

Ngodock H, Carrier M. 2014. A 4DVAR System for the Navy Coastal Ocean Model. Part II: Strong and Weak Constraint Assimilation Experiments with Real Observations in Monterey Bay. Monthly Weather Review, 142, 2108-2117.

Nicholson D, Emerson S, Eriksen CC. 2008. Net community production in the deep euphotic zone of the subtropical North Pacific gyre from glider surveys.Limnol. Oceanogr., 53(5, part 2), 2008, 2226-2236.

Nicholson, DP, Wilson ST, Doney SC, Karl DM. 2015. Quantifying subtropical North Pacific gyre mixed layer primary productivity from Seaglider observations of diel oxygen cycles. Geophys. Res. Lett., 42, 4032-4039. doi: 10.1002/2015GL063065.

Niewiadomska K, Claustre H, Prieur L, d'Ortenzio F. 2008. Submesoscale physicalbiogeochemical coupling across the Ligurian Current (northwestern Mediterranean) using a bio-optcal glider, Limnology and Oceanography, 53, 2210-2225.

Ohman MD, Rudnick DL, Chekalyuk A, Davis RE, Feely RA, Kahru M, Kim H-J, Landry MR, Martz TR, Sabine CL, Send U. 2013. Autonomous ocean measurements in the California Current Ecosystem. Oceanography 26(3):18-25, http://dx.doi.org/10.5670/oceanog.2013.41.

Oke PR, Sakov P, Schulz E. 2009. A comparison of shelf observation platforms for assimilation into an eddy-resolving ocean model. Dynamics of Atmospheres and Oceans, 48, 121-142.

Olita A, Sparnocchia S, Cusi S, Fazioli L, Sorgente R, Tintoré J, Ribotti A. 2014. Observations of a phytoplankton spring bloom onset triggered by a density front in NW Mediterranean. Ocean Science, 10, 657-666.

Oliver M, Breece MW, Fox DA, Haulsee DE, Kohut JT, Manderson J, Savoy T. 2013. Shrinking the haystack: using AUV in an integrated ocean observatory to map Atlantic Sturgeon in the coastal ocean.Fisheries, 38 (5), 210-216.

Omand, M, Perry M, D'Asaro E, Lee C, Briggs N, Cetinic I, Mahadevan A. 2015. Eddydriven subduction exports particulate organic carbon from the spring bloom, Science, 348(6231), 222-225, doi:10.1126/science.1260062. 
Palmer MR, Stephenson GR, Inall ME, Balfour C, Düsterhus A, Green JAM. 2015. Turbulence and mixing by internal waves in the Celtic Sea determined from ocean glider microstructure measurements. J. Mar. Syst. 144:57-69

Pan C, Zheng L, Weisberg RH, Liu Y, Lembke CE, 2014. Comparisons of different ensemble schemes for glider data assimilation on West Florida Shelf. Ocean Modelling, 81, 1324.

Pascual A, Ruiz S, Tintoré J. 2010. Combining new and conventional sensors to study the Balearic current. Sea Techn., 51, 7, 32-36.

Pattiaratchi CB, Hollings B, Woo M, Hanson C. 2010. Oceanographic observations of the Australian continental shelf and slope waters using autonomous ocean gliders. In J Hall, DE Harrison \& D Stammer (eds), Proceedings of OceanObs'09: sustained ocean observations and information for society conference/, ESA publication WPP306, Venice, 21-25 September 2009, doi: 10.5270/OceanObs09.

Pattiaratchi CB, Hollings B, Woo M, Welhena T. 2011. Dense shelf water formation along the south-west Australian inner shelf. Geophysical Research Letters, 38, L10609, doi: 10.1029/2011GL046816.

Pelland N, Eriksen C, Lee C. 2013.Subthermocline Eddies over the Washington Continental Slope as Observed by Seagliders, 2003-09. J. Phys. Oceanogr., doi:10.1175/JPO-D12-086.1.

Pelland NA, Sterling JT, Lea MA, Bond NA, Ream RR, Lee CM, Eriksen CC. 2014. Fortuitous Encounters between Seagliders and Adult Female Northern Fur Seals (Callorhinusursinus) off the Washington (USA) Coast: Upper Ocean Variability and Links to Top Predator Behavior. Plos One, 9.

Perry MJ, Sackman BS, Eriksen CC, Lee CM. 2008. Seaglider observations of blooms and subsurface chloropyll maxima off the Washington coast.Limnol.Oceanogr., 53(5, part 2), 2008, 2169-2179.

Pierce SD, Barth JA, Shearman RK, Erofeev AY. 2012. Declining Oxygen in the Northeast Pacific. J. Phys. Oceanogr., 42, 495-501. doi: http://dx.doi.org/10.1175/JPO-D-110170.1 .

Pietri A, Testor P, Echevin V, Chaigneau A, Mortier L, Eldin G, Grados C. 2013. Fine scale vertical structure of the upwelling system ofSouthern Peru as observed from glider data. J. Phys. Oceanogr., 43, 631-646. 
Powell JR, Ohman MD, 2012.Use of glider-class acoustic Doppler profilers for estimating zooplankton biomass. J. Plankton Res.34 (6), 563-568, doi: 10.1093/plankt/fbs023

Powell JR, Ohman MD. 2015. Covariability of zooplankton gradients with glider-detected density fronts in the Southern California Current System. Deep-Sea Res. II 112:79 90

Qiu C, Mao H, Yu J, Xie Q, Wu J, Lian S, Liu Q, Sea surface cooling in the Northern South China Sea observed using Chinese sea-wing underwater glider measurements, Deep Sea Research Part I: Oceanographic Research Papers, Volume 105, November 2015, Pages 111-118

Rainville L, Lee CM, Rudnick DL, Yang K-C. 2013. Propagation of internal tides generated near Luzon Strait: Observations from autonomous gliders, J. Geophys. Res. Oceans, 118, 4125-4138, doi:10.1002/jgrc.20293.

Ramp S, Davis R, Leonard N, Shulman I, Chao Y, Robinson A, Marsden J, Lermusiaux P, Fratantoni D, Paduan J. 2009. Preparing to predict: the second autonomous ocean sampling network (AOSN-II) experiment on the Monterey Bay. Deep-Sea Res. II 56, 68-87.

Ramp S, Lermusiaux P, Shulman I, Chao Y, Wolf R, Bahr F. 2011. Oceanographic and atmospheric conditions on the continental shelf north of the Monterey Bay during August 2006. Dyn. Atmos. Oceans 52, 192-223.

Rayburn JT, Todd J, Kamenkovich VM. 2013. Comparison of the observed mixed layer depth in the lee of the Hawaiian island to the modeledmoxed layer depth of the Regional Navy Coastal Model. Marine Tech. Soc. J., 47, 55-66.

Rudnick DL, Cole ST. 2011. On sampling the ocean using underwater gliders, J. Geophys. Res., 116, C08010, doi:10.1029/2010JC006849.

Rudnick DL, Gopalakrishnan G, Cornuelle BD. 2015. Cyclonic eddies in the Gulf of Mexico: observations by underwater gliders and simulations by numerical model. J. Phys. Oceanogr.

Rudnick DL, Johnston TMS, Sherman JT. 2013. High-frequency internal waves near the Luzon Strait observed by underwater gliders, J. Geophys. Res. Oceans, 118, 774-784, doi:10.1002/jgrc.20083. 
Ruiz S, Pascual A, Garau B, Faugere Y, Alvarez A, Tintoré J. 2009a. Mesoscale dynamics of the Balearic front integrating glider, ship and satellite data, Journal of Marine Systems, 78, S3-S16, doi: 10.1016/j.jmarsys.2009.01.007.

Ruiz S, Pascual A, Garau B, Pujol I, Tintoré J. 2009b. Vertical motion in the upper-ocean from glider and altimetry data. Geophysical Research Letters, L14607, doi:10.1029/2009GL03856.

Ruiz S, Renault L, Garau B, Tintoré J. 2012. Underwater glider observations and modeling of an abrupt mixing event in the upper ocean, Geophys. Res. Lett. 39: L01603.

Schaeffer A, Roughan M and Wood JE. 2014. Observed bottom boundary layer transport and uplift on the continental shelf adjacent to a western boundary current, J. Geophys. Res. Oceans, 119, 4922-4939, doi:10.1002/2013JC009735.

Schaeffer A, Roughan M. 2015. Influence of a western boundary current on shelf dynamics and upwelling from repeat glider deployments, Geophys. Res. Lett., 42, 121-128, doi:10.1002/2014GL062260.

Schlundt M, Brandt P, Dengler M, Hummels R, Fischer T, Bumke K, Krahmann G, Karstensen J. 2014. Mixed layer heat and salinity budgets during the onset of the 2011 Atlantic cold tongue, J. Geophys. Res. Oceans, 119, 7882-7910, doi:10.1002/2014JC010021.

Schofield, O, Kohut J, Glenn S, Morell J, Capella J, Corredor J, Orcutt J, Arrott M, Krueger I, Meisinger M, Peach C, Vernon F, Chave A, Chao Y, Chien S, Thompson D, Brown W, Oliver M, Boicourt W. 2010. A regional slocum glider network in the Mid-Atlantic Bight leverages broad community engagement. Marine Technology Society Journal 44, 185-195.

Schönau MC, Rudnick DL, Cerovecki I, Gopalakrishnan G, Cornuelle BD, McClean JL, Qiu B. 2015. The Mindanao Current: Mean structure and connectivity. Oceanography 28(4):34-45, http://dx.doi.org/10.5670/oceanog.2015.79.

Schönau MC, Rudnick DL. 2015. Glider observations of the North Equatorial Current in the western tropical Pacific. J. Geophys. Res. Oceans 120:3586-605

Seegers BN, Birch JM, Marin R, Scholin CA, Caron DA, Seubert EL, Howard MDA, Robertson G L, Jones BH. 2015. Subsurface seeding of surface harmful algal blooms observed through the integration of autonomous gliders, moored environmental 
sample processors, and satellite remote sensing in southern California. Limnol. Oceanogr., 60: 754-764. doi:10.1002/lno.10082

Sherwin TJ, Aleynik D, Dumont E, Inall ME 2015. Deep drivers of mesoscale circulation in the central Rockall Trough, Ocean Sci., 11, 343-359, doi:10.5194/os-11-343-2015, 2015.

Sherwin TJ, Read JF, Holliday NP, Johnson C. 2012. The impact of changes in North Atlantic Gyre distribution on water mass characteristics in the Rockall Trough. - ICES Journal of Marine Science, 69: 751-757.

Shulman I, Rowley C, Anderson S, DeRada S, Kindle J, Martin P, Doyle J, Cummings J, Ramp S, Chavez F, Fratantoni D, Davis R. 2009. Impact of glider data assimilation on the Monterey Bay model, Deep Sea Research Part II: Topical Studies in Oceanography, Volume 56, Issues 3-5, February 2009, Pages 188-198.

Shulman I, Anderson S, Rowley C, DeRada S, Doyle J, Ramp S. 2010. Comparisons of upwelling and relaxation events in the Monterey Bay area, J. Geophys. Res., 115, C06016, doi:10.1029/2009JC005483.

Stanev EV, Schulz-Stellenfleth J, Staneva J, Grayek S, Seemann J, Petersen W. 2011. Coastal observing and forecasting system for the German Bight—estimates of hydrophysical states. Ocean Sci., 7, pp. 569-583.

Swart S, Thomalla SJ, Monteiro PMS. 2014. The seasonal cycle of mixed layer dynamics and phytoplankton biomass in the Sub-Antarctic Zone: A high-resolution glider experiment, J. Mar. Syst., doi:10.1016/j.jmarsys.2014.06.002.

Thomalla S, Racault M-F, Swart S, Monteiro P. 2015. High-resolution view of the spring bloom initiation and net community production in the Subantarctic Southern Ocean using glider data. ICES Journal of Marine Science, 72: 1999-2020.

Thompson AF, Heywood KJ, Schmidtko S and Stewart AL. 2014. Eddy transport as a key component of the Antarctic overturning circulation, Nature Geoscience, doi:10.1038/ngeo2289.

Thomsen S, Kanzow T, Krahmann G, Greatbatch RJ, Dengler M, Lavik G. 2016. The formation of a subsurface anticyclonic eddy in the Peru-Chile Undercurrent and its impact on the near-coastal salinity, oxygen, and nutrient distributions, J. Geophys. Res. Oceans, 121, 476-501, doi:10.1002/2015JC010878. 
Timmermans M-L, Winsor P. 2013. Scales of horizontal density structure in the Chukci Sea surface layer. Continental Shelf Res., 52, 39-45,DOI: 10.1016/j.csr.2012.10.015.

Tintoré J, Vizoso G, Casas B, Heslop E, Pascual A, Orfila A, Ruiz S, Martínez-Ledesma M, Torner M, Cusí S, et al. 2013. SOCIB: The Balearic Islands Coastal Ocean Observing and Forecasting System Responding to Science, Technology and Society Needs. Mar. Technol. Soc. J. 47, 101-117. doi:10.4031/MTSJ.47.1.10.

Todd RE and Owens WB, Daniel L. Rudnick DL. 2015. Potential Vorticity Structure in the North Atlantic Western Boundary Current from Underwater Glider Observations. Journal of Physical Oceanography, 46, 327-348, doi: 10.1175/JPO-D-15-0112.1.

Todd RE, Rudnick DL, Davis RE, Ohman MD. 2011a. Underwater gliders reveal rapid arrival of El Niño effects off California's coast. Geophysical Research Letters, 38, doi:10.1029/2010GL046376.

Todd RE, Rudnick DL, Davis RE. 2009.Monitoring the greater San Pedro Bay region using autonomous underwater gliders during fall 2006. J. Geophys. Res., 114, doi:10.1029/2008JC005086.

Todd RE, Rudnick DL, Mazloff MR, Cornuelle BD, Davis RE. 2012. Thermohaline structure in the California Current System: Observations and modeling of spice variance, J. Geophys. Res., 117, C02008, doi:10.1029/2011JC007589.

Todd RE, Rudnick DL, Mazloff MR, Davis RE, Cornuelle BD. 2011b. Poleward flows in the southern California Current System: Glider observations and numerical simulation. Journal of Geophysical Research, 116, doi:10.1029/2010JC006536.

Ullgren JE, Fer I, Darelius E, Beaird N. 2014. Interaction of the Faroe Bank Channel overflow with Iceland Basin intermediate waters. Journal of Geophysical ResearchOceans, 119, 228-240.

Wall CC, Lembke C, Mann DA. 2012. Shelf-scale mapping of sound production by fishes in the eastern Gulf of Mexico, using autonomous glider technology. Mar. Ecol. Prog. Ser. $449,55-64$.

Weingartner T, Dobbins E, Danielson S, Winsor P, Potter R, Statscewich H. 2013. Hydrographic variability over the north eastern Chukchi Sea shelf in summer-fall 2008-2010. Continental Shelf Research, 67, 5-22. 
1 Wilkin JL, Hunter EJ. 2013. An assessment of the skill of real-time models of Mid-Atlantic

2

3

4

5

6

9

10

11

12

Bight continental shelf circulation, J. Geophys. Res. Oceans, 118, 2919-2933, doi:10.1002/jgrc.20223.

Willis, Z. 2013. US Integrated Ocean Observing System (IOOS (R)) delivering benefits and the Global HF Radar and Glider Initiative. 2013 MTS/IEEE OCEANS - Bergen, JUN 10-14 2013.

Xu Y, Chant RJ, Gong D, Castelao R, Glenn SM, Schofield O. 2011. Seasonal variability of chlorophyll a in the Mid-Atlantic Bight, Cont. Shelf Res., 31, 1640-1650.

Zhang WG, Wilkin JL, Levin JC. 2010. Towards an integrated observation and modeling system in the New York Bight using variational methods. Part II: Representer-based observing strategy evaluation. Ocean Modelling 35, 134-145.

Zhao J, Hu C, Lenes JM, Weisberg RH, Lembke C, English D, Wolny J, Zheng L, Walsh JJ, Kirkpatrick G. 2013. Three-dimensional structure of a Karenia brevis bloom: Observations from gliders, satellites, and field measurements, Harmful Algae, 29, Pages 22-30, http://dx.doi.org/10.1016/j.hal.2013.07.0 